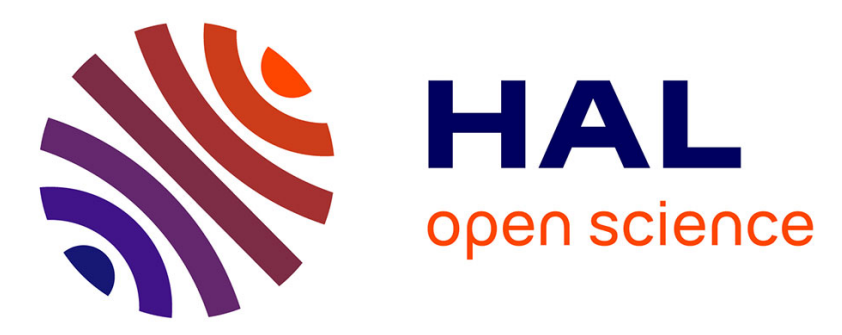

\title{
Ecotoxicological approach for assessing the contamination of a Hawaiian coral reef ecosystem (Honolua Bay, Maui) by metals and a metalloid
} Laetitia Hédouin, Marc Metian, Ruth D Gates

\section{- To cite this version:}

Laetitia Hédouin, Marc Metian, Ruth D Gates. Ecotoxicological approach for assessing the contamination of a Hawaiian coral reef ecosystem (Honolua Bay, Maui) by metals and a metalloid. Marine Environmental Research, 2011, 71 (3), pp.149. 10.1016/j.marenvres.2010.12.006 . hal-00673206

\section{HAL Id: hal-00673206 https://hal.science/hal-00673206}

Submitted on 23 Feb 2012

HAL is a multi-disciplinary open access archive for the deposit and dissemination of scientific research documents, whether they are published or not. The documents may come from teaching and research institutions in France or abroad, or from public or private research centers.
L'archive ouverte pluridisciplinaire HAL, est destinée au dépôt et à la diffusion de documents scientifiques de niveau recherche, publiés ou non, émanant des établissements d'enseignement et de recherche français ou étrangers, des laboratoires publics ou privés. 


\section{Accepted Manuscript}

Title: Ecotoxicological approach for assessing the contamination of a Hawaiian coral reef ecosystem (Honolua Bay, Maui) by metals and a metalloid

Authors: Laetitia Hédouin, Marc Metian, Ruth D Gates

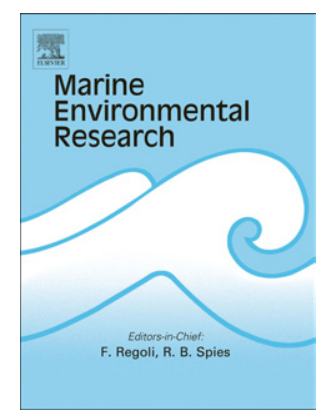

PII: $\quad$ S0141-1136(10)00194-7

DOI: $\quad$ 10.1016/j.marenvres.2010.12.006

Reference: MERE 3494

To appear in: Marine Environmental Research

Received Date: 10 December 2009

Revised Date: 16 December 2010

Accepted Date: 18 December 2010

Please cite this article as: Hédouin, L., Metian, M., Gates, R.D. Ecotoxicological approach for assessing the contamination of a Hawaiian coral reef ecosystem (Honolua Bay, Maui) by metals and a metalloid, Marine Environmental Research (2010), doi: 10.1016/j.marenvres.2010.12.006

This is a PDF file of an unedited manuscript that has been accepted for publication. As a service to our customers we are providing this early version of the manuscript. The manuscript will undergo copyediting, typesetting, and review of the resulting proof before it is published in its final form. Please note that during the production process errors may be discovered which could affect the content, and all legal disclaimers that apply to the journal pertain. 
1 Ecotoxicological approach for assessing the contamination of a Hawaiian

2 coral reef ecosystem (Honolua Bay, Maui) by metals and a metalloid

3

4 5

6

7

8

9

10

11

12

13

14

15
Laetitia Hédouin $^{1}$, Marc Metian $^{1}$ and Ruth D Gates ${ }^{1}$

${ }^{1}$ Hawai ${ }^{i}$ Institute of Marine Biology, 46-007 Lilipuna road, 96744, Hawai ‘i, United States

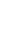
7

*Corresponding author: $\quad$ Laetitia Hédouin

Hawaii Institute of Marine Biology, University of Hawaii

46-007 Lilipuna road

Hawaii, 96744, United States

E-mail: hedouinlaetitia@yahoo.fr

Phone: +1 (808) 6361279

Fax: +1 (808) 236-7443 


\section{Abstract}

The goal of this study was to assess the contamination of Honolua Bay using an ecotoxicological approach. First, the concentrations of 9 contaminants (metals and metalloid) were assessed in sediments and tropical marine organisms (alga Halimeda kanaloana, goatfish Parupeneus multifasciatus and urchin Tripneustes gratilla) sampled from Honolua and surrounding Bays. Then, the ecological parameters characterizing coral health (e.g. coral cover) were evaluated in Honolua Bay in the context of these contaminants. High concentrations of Co, $\mathrm{Cr}, \mathrm{Mn}, \mathrm{Ni}$, and $\mathrm{V}$ in sediments from Honolua and Honokohau Bay were measured, but these concentrations were not mirrored in the organisms examined, except for Mn, suggesting that the metals are generally bound in chemically inert forms in these sediments. Moreover, few anthropogenic activities impact these bays and so the elevated $\mathrm{Co}, \mathrm{Cr}, \mathrm{Mn}, \mathrm{Ni}$ and $\mathrm{V}$ concentrations in sediments appear to stem from their high natural background in Honolua and Honokohau watersheds. An analysis of the relationship between the ecological parameters and metal concentrations in Honolua Bay revealed a significant correlation between coral cover and $\mathrm{Co}, \mathrm{Cr}, \mathrm{Mn}, \mathrm{Ni}, \mathrm{V}, \mathrm{Zn}$ concentrations in sediments, with coral cover decreasing with increasing metal concentration. Collectively, however, the data suggest that a complex mixture of landbased stressors (e.g. sediment, metals, nutrients) affect the coral health in Honolua Bay, rather than metal stress alone. 


\section{INTRODUCTION}

Coral reefs are one of the most diverse and biologically complex marine ecosystems on earth. However there is now deep concern whether coral reefs will survive shifts in the marine environment associated with global changes and local stresses (e.g. Hoegh-Guldberg et al. 2007, Wilkinson 1999). Bryant et al (1998) report that 58 percent of the world's reefs are at risk from human activities, and that coastal development poses one of the most serious among these threats. Indeed, the expansion of human populations in coastal areas and the accompanying urbanization and agricultural activities, have increased the discharge of industrial wastes and untreated sewages onto the adjacent coral reefs. Such local activities have resulted in high metal concentrations in seawater, sediments, corals and tissues of other reef organisms sampled from a number of tropical ecosystems (e.g. Brown and Holley 1982, Hanna and Muir 1990). The adverse effects of metal contaminants on coral reefs have led to reduced growth and reproduction, coral death and loss of biodiversity (e.g. Negri et al. 2002, Richmond 1993). Metals have also been recognized as an environmental trigger that can induce bleaching of corals (e.g. David 2003, Scott and Davies 1997). As such, metal contamination in urban aquatic ecosystems is a major concern. In the Hawaiian Islands, a combination of basaltic rocks and large human populations with high traffic densities have led to elevated concentrations of copper, chromium, lead and zinc in streambed sediments (Andrews and Sutherland 2004, McMurtry et al. 1995), which in some cases, exceed the aquatic-life guidelines (De Carlo et al. 2005). While metal concentrations in streambed sediments from the Hawaiian Islands are relatively well known, with the exception of two studies, one in Kane'ohe Bay (Hunter et al. 1995) and one in French Frigate Shoals in the North Western Hawaiian Islands (Miao et al. 2001), concentrations in sediments and biota from coastal reef areas are not well characterized. To address this 
knowledge gap, the Coral Reef Land Based Pollution Local Action Strategy (CRLBP-LAS) identified three watersheds in the main Hawaiian Islands as focal areas for studies to better understand the threats that land-based contaminants pose to the near shore coral reef ecosystems. Within this framework, an assessment of metal and metalloid concentrations in three reef sites revealed very high concentrations of $\mathrm{Co}, \mathrm{Cr}, \mathrm{Ni}$ and $\mathrm{Mn}$ in sediments from Honolua Bay, Maui ( $<464 \mu \mathrm{g} \mathrm{Ni} \mathrm{g}^{-1} \mathrm{dwt}$ ) as compared to the Southern fringing reef of Moloka'i and Kane'ohe Bay, Oahu (<27 $\mu \mathrm{g}$ Ni g ${ }^{-1}$ dwt; Hédouin et al. 2009). Ni concentrations in Honolua Bay were 9 times higher than the Effective Range-Median for Sediment Quality Criteria (Long et al. 1995, NOAA 1999), which is in the range observed in reef areas impacted by Ni mining activities such as in New Caledonia (e.g. 797 to $900 \mathrm{~g} \mathrm{Ni} \mathrm{g}^{-1}$ dwt, Hédouin et al. 2008a), and definitely high enough to elicit adverse biological effects.

The difference between contamination and pollution is sometimes misunderstood and thus the terms are often misused. All pollutants are contaminants, but not all contaminants are pollutants (Chapman 2007, Warnau 1996). Elements or compounds are considered as contaminants when they are in concentrations over natural background whereas contaminants are considered as pollutants when they have an anthropogenic origin and negatively influence the environment, organisms, human health or human activities (GESAMP 1984). Metals and metalloid are naturally present in earth (Salomons and Forstner 1984), so their presence in sediments and biota is not always indicative of pollution. For this reason, we use the term contamination and contaminant to refer to the metals and metalloid in this paper.

The aims of the present study were to: 1) evaluate whether contaminant concentrations measured in Honolua Bay are unique to this bay by providing a comprehensive baseline of Arsenic (As), cobalt $(\mathrm{Co})$, chromium $(\mathrm{Cr})$, copper $(\mathrm{Cu})$, manganese $(\mathrm{Mn})$, nickel $(\mathrm{Ni})$, lead $(\mathrm{Pb})$, 
vanadium (V) and zinc ( $\mathrm{Zn})$ in reef sediments from Honolua Bay and adjacent bays in the West Maui region; 2) assess the bioavailability of metals and metalloid to the reef biota (the alga Halimeda kanaloana, the goatfish Parupeneus multifasciatus and the urchin Tripneustes gratilla); and 3) explore the relationship between coral ecology and the gradient of metal and metalloid contamination in Honolua Bay.

\section{MATERIALS AND METHODS}

\subsection{Description of Honolua Bay, West Maui, Hawai 'i}

Honolua Bay has been a Marine Life Conservation District since 1978 and is divided into 3 broad regions (Fig. 1), that include (1) a fringing reef that extends into the bay and borders the north and south shorelines with a coral cover averaging $10.3 \%$ on the north side and $23.3 \%$ on the south side (CRAMP 2004), (2) a deeper sandy bottom area localized between the reefs, and (3) an inner bay composed of silt, sand, boulder bottom with corals present but reefs absent. This last area is the closest to the Honolua Stream and reflects this proximity by in its higher turbidity, lower salinity and higher dissolved nutrients (e.g. $\mathrm{NO}_{3}{ }^{-}$) (Marine Research Consultants Inc 2007). Honolua Stream is an interrupted perennial stream with an average stream flow of 19 million liters $\mathrm{d}^{-1}$ in the upper elevations. A detailed description of coastal circulation and sediment dynamics of the study area has been conducted by the United States Geological Survey (USGS) (e.g. Storlazzi and Jaffe 2003, Storlazzi et al. 2004, Storlazzi and Presto 2005).

\subsection{Sample collection for metal and metalloid analyses}

Four stations were selected in Honolua Bay for this study, two in the inner bay (Honolua1 = Hon1, Honolua3 $=$ Hon3) and two on the reef bed offshore $($ Honolua2 $=$ Hon2, Honolua4 = Hon4; Fig. 1). To better understand the degree of contamination in West Maui relative to Honolua Bay, other sampling sites were selected North of Honolua Bay (Honokohau Bay and 

Lipoa Point) and South of Honolua Bay (Mokulei‘a Bay, Kapalua Bay and Honokeana Cove). Reef sediments and organisms (depending on their availability) were collected from each of these sites (Fig. 1). Honolua Bay is a Marine Life Conservation District and sampling of marine organisms requires a permit from the Division of Aquatic Resources (DAR). Permits were issued for collections of the alga Halimeda kanaloana, the goatfish Parupeneus multifasciatus and the urchin Tripneustes gratilla, but not for corals. Indeed these organisms are proposed as potential bioindicator species since they respond to most of the criteria that should be met by a bioindicator species. They are widely distributed in the West coast of Maui, available all year long and easy to collect (e.g. Moore 1966, Phillips 1990, Warnau et al. 1998). In addition since the selected organisms represent different trophic levels, the combination of data from these different organisms allow for a broader assessment of the bioavailability of metals and metalloid present in the marine environment.

\subsubsection{Sampling of marine organisms and sediments}

All organisms were collected between September 12 - 23, 2007. H. kanaloana was collected from Honolua Bay and Honokeana Cove. Epiphytes and sediments were removed from the algae by gentle scrubbing and thorough rinsing with clean $5-\mu \mathrm{m}$ filtered seawater. P. multifasciatus (n $=6$; mean \pm S.D.: length: $24.2 \pm 1.7 \mathrm{~cm}$ ) were collected in Honolua Bay by spear fishing and samples of liver and muscle removed by dissection. T. gratilla between 79.7 and $84.2 \mathrm{~mm}$ in size were collected on snorkel from Honolua Bay, Kapalua Bay, Lipoa Point and Honokeana Cove (n $=7$ per location, except for Lipoa Point $\mathrm{n}=4$ ). Urchins were kept alive for $24 \mathrm{~h}$ in plastic boxes containing $30 \mathrm{~L}$ of $5-\mu \mathrm{m}$ filtered seawater (from the same sampling stations) to allow the gut contents and particulates to be excreted and shed. Sampled animals were dissected to separate gonads, intestine and body wall (including spines). The tissues sampled from each organism were weighed (wet wt), dried at $60{ }^{\circ} \mathrm{C}$ until the weight was constant, and then re-weighed (dry 
wt). Dried biological samples were hermetically sealed in PET containers until analyzed for metal and metalloid contents.

Superficial sediments $(50-100 \mathrm{~g}, \mathrm{n}=5$ replicates) were collected from all 6 sampling locations along the West coast of Maui (Fig. 1). These were placed in acid-washed PET bags and frozen $\left(-20^{\circ} \mathrm{C}\right)$ until analyzed. Each sample was dried at $60{ }^{\circ} \mathrm{C}$ until the weight was constant, $(5$ d), sieved (4-mm mesh size) to eliminate stones and fragment of corals, ground using a mortar and pestle and stored in acid-washed and hermetically sealed in PET containers until analyzed for metal and metalloid contents.

\subsubsection{Analyses}

As, $\mathrm{Co}, \mathrm{Cr}, \mathrm{Cu}, \mathrm{Mn}, \mathrm{Ni}, \mathrm{Pb}, \mathrm{V}$ and $\mathrm{Zn}$ were analyzed by the Agricultural Diagnostic Service Center, at the University of Hawai'i. Aliquots of biological samples (0.5 g) and sediment samples $(0.5 \mathrm{~g})$ were digested with $5 \mathrm{ml}$ of $65 \% \mathrm{HNO}_{3}$ (Merck, suprapur quality). Concentrations of metals were determined using Atom San 16 ICP (Thermo Jarrell Ash Corporation, Franklin, MA). Two control samples (one Certified Reference Materials -CRMlobster hepatopancreas TORT-2 (NRCC) and one blank) treated and analyzed in the same way as the samples were included in each analytical batch. The results for CRM indicated recoveries ranging from $86 \%(\mathrm{Cu})$ to $115 \%(\mathrm{~Pb})$. Mean element concentrations were given on a dry weight basis $\left(\mu \mathrm{g} \mathrm{g}^{-1} \mathrm{dwt}\right)$.

\subsubsection{Statistical analyses}

Comparisons of the data were performed using one- or two-way analysis of variance (ANOVA) followed by the multiple comparison test of Tukey (Zar 1996). Two-way ANOVA was used with sampling location and body compartment as fixed factors. The variability explained by each factor and their interactions were derived from the sum of squares (Zar 1996).

The correlation and statistical significance of the relationship between the metal concentrations 
in sediments and those in different body compartments of the urchin P. lividus were evaluated using Pearson's correlation coefficient with the software R (Hornik 2010). The level of significance for statistical analyses was set at $\alpha=0.05$.

\subsection{Coral ecology survey}

Ecological surveys were performed at the four stations in Honolua Bay (depth ranging from 1.5 to $2.5 \mathrm{~m}$ ) to evaluate whether any traits in the coral ecology were correlated with the gradient of metal and metalloid concentrations observed in sediments, (Fig. 1). Six $20 \mathrm{~m}$ long transects were deployed randomly at each station and sampled using a line-intercept method (Hill and Wilkinson 2004). Percent cover was estimated by dividing the substrate into 6 categories: boulder bottom, reef bed, sand, alga, dead coral, and live coral. Individual coral colonies under each transect were identified to species and the size of the colony approximated by measuring maximum length, width and height. The condition of the colony was assessed for partial mortality as defined as percentage of the surface area of the colony that was dead. Colonies were also assigned to a category based on color. The color categories used were healthy, bleached, partially bleached and pale. Corals classified as healthy showed no signs of tissues discoloration; bleached coral colonies were totally white; partially bleached corals had patches of fully white tissues interspersed within the darker colored healthy tissues; and pale corals were globally paler in color than healthy colonies of the same species. Hobo® data loggers were deployed at each station (1.5 to $2.5 \mathrm{~m}$ depth) to record temperature and light over $6 \mathrm{~d}$ at a sampling interval of 15 min. Seawater samples $(1500 \mathrm{ml}, \mathrm{n}=3$ per station $)$ were collected on September $17^{\text {th }}, 18^{\text {th }}$ and $19^{\text {th }}, 2007$ and filtered through GF/C filter to estimate the turbidity of seawater $\left(\mathrm{mg}^{-1}\right)$.

The coral cover was compared among stations using one-way ANOVA and appropriate posthoc multiple range tests. Relationships between ecological parameters, environmental variables and sediment associated metal and metalloid concentrations were examined using correlation 
179 (Spearman) and linear regression analysis using average values for whole station reefs using 180 SPSS® statistical software 16.0 (SPSS Inc., Chicago, IL, USA).

\section{RESULTS}

\subsection{Sediments}

\subsubsection{Honolua Bay}

The four stations in Honolua Bay can be ranked according to their degree of contamination Hon $1>$ Hon $3>$ Hon $2>$ Hon 4 with Hon 1 being the most contaminated by all elements except $\mathrm{Cu}$ and $\mathrm{Fe}$, and Hon4 the least (Table 1). Statistical analyses of the data are presented in Figure 2A1. Results indicate that the concentrations of $\mathrm{Co}, \mathrm{Mn}, \mathrm{Ni}, \mathrm{V}$ and $\mathrm{Zn}$ in sediments were significantly different among all stations. Concentrations of $\mathrm{Cr}$ and $\mathrm{Cu}$ were similar at Hon1 and Hon3, and at Hon2 and Hon4, respectively. No significant differences were observed for the Fe concentrations in sediments at Hon1, Hon2 and Hon3. There was no significant difference in the concentration of $\mathrm{Pb}$ measured in sediments at the four stations. For As, no significant difference was observed in sediments between station Hon1 and Hon3, and Hon1 and Hon2.

\subsubsection{Honolua Bay and other adjacent Bays}

One-way ANOVA was performed on element concentration measured in sediments collected from the different bays in the West Maui. For Honolua Bay, Hon1 and Hon4 were chosen for the statistical analyses because they have the broadest range of contamination (Fig. 2-A1). Sediments collected at Honokohau Bay were more contaminated than those collected from the other bays surrounding Honolua Bay and the concentrations of contaminants were in the range of those measured in the most contaminated stations of Honolua Bay (Hon1 and Hon3, Table 1). For example, Ni concentrations were $374 \mu \mathrm{g} \mathrm{g}^{-1} \mathrm{dwt}$ and 303 - $481 \mu \mathrm{g} \mathrm{g}^{-1} \mathrm{dwt}$ in Honokohau Bay and Honolua Bay (Hon1 and Hon3), respectively. In addition, statistical analyses (Fig. 2-A2) 
indicate that the concentrations of most contaminants measured in sediments from Hon1 and Honokohau Bay were generally higher than those measured in sediments from other bays, and that concentrations of $\mathrm{Co}, \mathrm{Fe}, \mathrm{Mn}, \mathrm{V}$ and $\mathrm{Zn}$ measured in sediments from Hon1 and Honokohau Bay were not significantly different from one another. In contrast, metal and metalloid concentrations measured in sediments from Hon4, Lipoa Point, Kapalua Bay and Honokeana Cove were similar and lower than Honokokau Bay and Honolua sites Hon1 and Hon3. No significant difference was observed for $\mathrm{Co}, \mathrm{Cr}, \mathrm{Cu}, \mathrm{Ni}, \mathrm{Pb}, \mathrm{V}$ and $\mathrm{Zn}$ among sediments from Hon4, Lipoa Point and Kapalua Bay.

\subsubsection{Sediment Quality Guidelines}

Element concentrations in sediments from all stations were compared to the NOAA Sediment Quality Guidelines (Long et al. 1995, NOAA 1999) that were developed to define the concentrations of metals and metalloid that have adverse effects on biological organisms. Within this framework, the Threshold Effect Level (TEL) represents the concentration below which adverse effects rarely occur; the Effect Range-Low (ERL) corresponds to concentration above which negative effects are more common, and the Effect Range-Median (ERM) corresponds to concentrations at or above which negative effects frequently occur. Results of the comparison are presented in Table 1.

\subsection{Reef biota}

Except for $\mathrm{Fe}\left(\mathrm{p}_{\text {Tukey }}<0.05\right)$ and $\mathrm{Mn}\left(\mathrm{p}_{\text {Tukey }}<0.01\right)$ there was no significant difference in the element concentrations measured in the alga H. kanaloana collected from Honokeana Cove and Honolua Bay (Table 2).

Concentrations of $\mathrm{Co}, \mathrm{Cu}, \mathrm{Fe}, \mathrm{Mn}$, and $\mathrm{Zn}$ measured in the livers of the goatfish $P$. multifasciatus were one to two orders of magnitude higher than in the muscle (Table 2). Very high Fe concentrations were recorded in goatfish livers reaching $4,400 \mu \mathrm{g} \mathrm{g}^{-1} \mathrm{dwt}$ compared to 
$<16 \mu \mathrm{g} \mathrm{g}^{-1} \mathrm{dwt}$ in muscle. Since individuals of $P$. multifasciatus were all collected from Honolua Bay, it was not possible to compare concentrations measured with other geographical areas.

The element concentrations measured in the gonads, intestines and body wall of the urchin T. gratilla collected from stations inside and outside Honolua Bay are presented in Table 2. Statistical analyses performed on the element concentrations in urchins collected from stations inside Honolua Bay (Hon1 and Hon4) and in Honokeana Cove, Lipoa Point and Kapalua Bay indicated that body compartment explained the majority of the variability for $\mathrm{As}, \mathrm{Cu}, \mathrm{Fe}, \mathrm{V}$, and $\mathrm{Zn}$ (accounting for 52 to $89 \%$ of the global variance). Sampling station explained $40 \%$ of the variability for $\mathrm{Mn}$ and 23 to $30 \%$ of the variability observed for $\mathrm{Cr}$ and $\mathrm{Cu}$, respectively. For $\mathrm{Co}$, $\mathrm{Cr}, \mathrm{Cu}, \mathrm{Ni}, \mathrm{Pb}$, and $\mathrm{Zn}$, an important part of the variation was associated with the residual term, ranging from 28 to $49 \%$, indicating that other, non-investigated factors (biological and/or environmental factors) were also influencing element concentrations in these urchin tissues.

238 Multiple comparison tests on the mean concentrations of elements in each sampling location (all body compartments together) indicated that the concentrations of As, Co, and $\mathrm{Mn}$ were significantly higher $\left(\mathrm{p}_{\text {Tukey }}<0.05\right)$ in urchins from station Hon1 compared to those from the four 241 other stations (Fig. 2-B1). $\mathrm{Cr}$ and $\mathrm{Cu}$ concentrations in urchins from station Hon4 were 242 significantly higher $\left(\mathrm{p}_{\text {Tukey }}<0.05\right)$ than those measured in urchins from Honokeana Cove. Ni 243 concentrations in urchins from Hon1 and Hon4 were not significantly different, but significantly 244 higher than those from urchins collected at Honokeana Cove and Kapalua Bay $\left(\mathrm{p}_{\text {Tukey }}<0.05\right.$ ). 245 No significant difference was observed for $\mathrm{Zn}$ concentrations in urchins from the five stations. 246 Multiple comparison tests on the mean concentrations in each body compartment (all sampling 247 locations together) indicated that the concentrations of $\mathrm{As}, \mathrm{Co}, \mathrm{Cu}, \mathrm{Fe}, \mathrm{Mn}$ and $\mathrm{Ni}$ were 248 significantly higher $\left(\mathrm{p}_{\text {Tukey }}<0.01\right.$, except for Co $\left.\mathrm{p}_{\text {Tukey }}=0.05\right)$ in the intestine than in the other 
body compartments (Fig. 2-B2). Zn concentrations in intestine and gonads were not significantly different, but significantly higher $\left(\mathrm{p}_{\text {Tukey }}<0.0001\right)$ than those in body wall. $\mathrm{Cr}, \mathrm{Pb}$ and $\mathrm{V}$ concentrations were significantly higher $\left(\mathrm{p}_{\text {Tukey }}<0.0001\right)$ in the body wall compared to the other body compartments. correlations with their respective concentrations in sediments (Pearson coefficient from 0.51 to 0.80, see Fig. 3). Significant correlations were also observed for $\mathrm{Co}, \mathrm{Mn}, \mathrm{Ni}$ and $\mathrm{Zn}$ between concentration in urchin gonads and sediments (Pearson coefficient from 0.45 to 0.78 , Fig. 3). Mn concentrations in urchin carapaces were also significantly correlated with $\mathrm{Mn}$ sediment concentrations (Pearson coefficient of 0.87, Fig. 3).

\subsection{Ecological survey}

In Honolua Bay, total live coral cover was 10.9 and $13.4 \%$ at the two inner stations (Hon1 and Hon3, respectively) and 17.4 and $26.2 \%$ on the two offshore stations (Hon2 and Hon4, respectively) (Fig. 4). Live coral cover was significantly lower at station Hon1 compared to Hon4 $\left(\mathrm{p}_{\text {Tukey }}=0.017\right)$, while no significant difference was observed among the other stations. Data from the ecological survey clearly indicated the presence of two types of stations in the bay. Stations Hon1 and Hon3 were characterized by a high percentage of boulder bottom (from 64 to $78 \%$ ), whereas the stations offshore were mainly composed of reef bed structure (38 to $81 \%$ ) (Fig. 4). The major species encountered in order of abundance were Porites lobata (percent of total number of colonies $=36.3 \%)$, Montipora patula $(17.7 \%)$, Montipora capitata $(14.6 \%)$, Pocillopora meandrina (14.2\%), and Porites compressa (6.6 \%) (Fig. 4). These five species were present at all four stations in Honolua Bay, except $P$. compressa, which was absent from Hon1. Other coral species were present but at low abundances $(<5 \%)$. 
Based on the color categories defined in $\S 2.3$, corals present at station Hon2 were mainly healthy $(78 \%)$ compared to the other three stations where corals showed more pronounced signs of bleaching (56 - $77 \%$, Fig. 4). Statistical analyses (one-way ANOVA) were performed on the diameter of colony, partial mortality and the proportion of the colony that was bleached (Pale, Bleach and Partially Bleach) (after $\arcsin (\sqrt{ } \mathrm{x})$ transformation) for the five most abundant coral species present in Honolua Bay $(P$. lobata, M. patula, M. capitata, $P$. meandrina and $P$ compressa). Results indicated that there was no significant difference in the colony diameters and partial mortality among stations except for $P$. lobata. Colonies of $P$. lobata had a significantly higher diameter at station Hon4 as compared to the three other stations (Hon4 > Hon2 $=$ Hon $3=$ Hon $\left.1 ; \mathrm{p}_{\text {Tukey }}<0.002\right)$, and a higher percentage of partial mortality $($ Hon4 = Hon2 $>$ Hon3 = Hon 1; $\left.\mathrm{p}_{\text {Tukey }}<0.05\right)$.

Results of the correlation matrices performed on the different ecological parameters and environmental conditions (element concentrations) indicated that total live coral cover was negatively correlated with $\mathrm{Co}, \mathrm{Cr}, \mathrm{Mn}, \mathrm{Ni}, \mathrm{V}$, and $\mathrm{Zn}$ concentration in sediments (-0.955 to 0.979, pearson $<0.05$, Table 3), but significant linear regressions were only observed for Co and V (Fig. 5). In addition, for the coral P. compressa, partial mortality was correlated positively to the diameter of the colony $(0.568$, p Pearson $<0.05)$.

The turbidity measured in Honolua Bay ranged from 14.5 (Hon4) to 68.2 (Hon1) mg $1^{-1}$. No significant difference was observed among the four stations in Honolua Bay on September 17 and 19, 2007, whereas the turbidity at Hon1 on September 18, 2007 was significantly higher by a factor of 3.8 compared to the other three stations in the bay (Fig. 6). Seawater temperature in Honolua Bay ranged from 26.2 to $28.5{ }^{\circ} \mathrm{C}$ and no difference was observed among the four selected stations. The salinity of seawater measured at the surface and $1.50 \mathrm{~m}$ depth ranged from 
36.2 to 36.9 parts per thousand (ppt) except for September 18, 2007, when a rain event occurred.

At the latter date, salinity of seawater decreased to $18.2 \mathrm{ppt}$ at the Hon1, and a slight decrease of salinity was also observed at the three other stations ( 32.1 to $35.6 \mathrm{ppt}$ ) compared to the other sampling times (September 17 and 19, 2007).

\section{DISCUSSION}

Sediments are sinks for contaminants (Salomons et al. 1987), therefore the measurement of metal and metalloid concentrations in reef sediments provides basic and essential information on the degree of contamination of the reef environment. Element concentrations measured in sediments collected from Honolua Bay displayed a very wide range of concentrations, from 2.71 $\mu \mathrm{g} \mathrm{g}^{-1} \mathrm{dwt}$ for Co up to $7,023 \mu \mathrm{g} \mathrm{g}^{-1} \mathrm{dwt}$ for Fe. Most interestingly, some elements such as Co, $\mathrm{Cr}, \mathrm{Mn}, \mathrm{Ni}$ and $\mathrm{V}$ reached very high concentration (e.g. up to $481 \mu \mathrm{g} \mathrm{g}^{-1} \mathrm{dwt}$ for $\mathrm{Ni}$ ). A recent study has confirmed that the concentration of $\mathrm{Co}, \mathrm{Cr}, \mathrm{Mn}, \mathrm{Ni}$ and $\mathrm{V}$ in reef sediments from Honolua Bay are elevated when compared to two other watersheds in Hawaii (SE Moloka' $i$ and Kane'ohe Bay) (Hédouin et al. 2009). In addition, among the four stations investigated, a clear gradient of element concentrations was observed, suggesting that the degree of contamination present in Honolua Bay is related to the discharge of sediments from Honolua Stream. To better understand the source of the elevated concentrations of metal and metalloid contamination in Honolua Bay, we investigated element concentrations in sediments from bays surrounding Honolua Bay. Concentrations of all elements measured in sediments collected at Honokohau Bay, located to the North of Honolua Bay, were very similar to the concentrations of contaminants measured in the most contaminated stations in Honolua Bay, Hon1 and Hon3, (e.g. 376 - 594 vs. $492 \mu \mathrm{g} \mathrm{Mn} \mathrm{g}{ }^{-1}$ dwt, 303 - 481 vs. $374 \mu \mathrm{g} \mathrm{Ni} \mathrm{g}^{-1}$ dwt, for Honolua Bay - Hon1 and Hon3- and Honokohau Bay, respectively). Comparison of $\mathrm{As}, \mathrm{Cr}, \mathrm{Cu}, \mathrm{Ni}, \mathrm{Pb}$ concentrations in 
sediments from Honolua Bay and/or Honokohau Bay with Sediment Quality Guidelines (NOAA 1999) indicate that $\mathrm{Cr}, \mathrm{Ni}$, and $\mathrm{Pb}$ are in high enough concentration to elicit negative effects on biota. The similarity observed in element concentrations of sediments from both bays suggests that these bays may be contaminated by the same source. Interestingly, a ditch (Honokohau ditch) was built in 1904 to divert the flow of the Honokohau stream for off-stream uses (Fontaine 2003). The Honokohau ditch is $2.9 \mathrm{~km}$ long and links Honolua Bay and Honokohau Bay. This connection may explain why the metal concentrations observed in sediments of the two bays are so similar. Honolua and Honokohau watersheds are mainly forested (69 and 83 \%, respectively; Parham et al. 2008), and support few anthropogenic activities. This indicates that the elevated concentrations of $\mathrm{Co}, \mathrm{Cr}, \mathrm{Mn}, \mathrm{Ni}, \mathrm{V}$ and $\mathrm{Zn}$ reflect the geology of the area and stem from high natural background in both Honolua and Honokohau watersheds as suggested by Hédouin et al. (2009) for Honolua Bay.

Regardless of the origin of the high concentrations of metals observed in sediments of Honolua Bay, the question is whether the contaminants are bioavailable and are adversely affecting the health of reef biota. Ni bound in the lattice of naturally occurring silicate minerals (e.g., olivine or pyroxenes) is less available for uptake by marine organisms as compared to water-soluble forms (CEPA 1994). That said, it is extremely difficult to predict how sedimentbound metals bioaccumulate in aquatic organisms in any given location because their bioavailability depends on their mineralogical origin (Kabata-Pendias 2001), characteristics of the sediments such as $\mathrm{pH}$, oxidation-reduction potential, ionic strength, type, and concentration 338 of organic and inorganic ligands (e.g. Callahan et al. 1979, Snodgrass 1980), and biological and 339 physiological traits of the organism (e.g. species, age, sexual cycle, Boyden 1977, Cossa et al. 340 1979, Eisler 1981). 
In this context, the measurement of elements in reef organisms from different trophic levels

342 (alga, fish, urchins) collected from Honolua Bay and surrounding bays provides a snapshot view

343 of the bioavailability of metals and a metalloid from the various sampling stations. The alga $H$.

344 kanaloana was chosen to investigate the metal bioaccumulation in Honolua Bay because it is

345 abundant in these areas and Halimeda species are generally efficient bioaccumulators of metals

346 (Al-Shwafi and Rushdi 2008). Comparison of metal and metalloid concentrations measured in

347 alga from Honolua Bay and Honokeana Cove indicated that while the sediments in these bays

348 are characterized by very different degrees of contamination, with the exception for $\mathrm{Fe}$ and $\mathrm{Mn}$,

349 element concentrations in alga were low and similar between sites, and in the same range of

350 concentrations reported in the literature for Halimeda species (see Table 4). These results suggest

351 that either there are low concentrations of dissolved metals in Honolua Bay (with the exception

352 of $\mathrm{Mn}$ and $\mathrm{Fe}$ ) or this species of Halimeda does not bioaccumulate metals efficiently. The

353 concentrations of contaminants in the goatfish $P$. multifasciatus from Honolua Bay are also low

354 and similar to those measured in other non-contaminated areas (e.g. Mauritania coast, Manila,

355 French Frigate Shoals -Hawai'i- see Table 4), supporting the conclusion that the contaminants in

356 sediments from Honolua Bay are not bioavailable to this fish species.

357 The urchin T. gratilla collected in Honolua Bay had higher concentrations of $\mathrm{As}, \mathrm{Co}, \mathrm{Cr}, \mathrm{Cu}$,

$358 \mathrm{Mn}$ and Ni than those from less contaminated stations along the West Coast of Maui (e.g.

359 Honokeana Cove, Kapalua Bay). However, while a clear gradient of $\mathrm{As}, \mathrm{Co}, \mathrm{Cr}, \mathrm{Cu}$ and $\mathrm{Ni}$

360 contamination was observed in sediments, the trend was less pronounced in urchin tissues (and

361 non-existent for algae) and significant correlations between metal concentrations in sediments

362 and those in the urchins T. gratilla were only observed for some metals (e.g. Co, Mn, Ni) and for

363 certain urchin body compartments. For example, Ni concentration in sediments collected inside 
Honolua Bay were up to 48 times higher than those measured in sediments outside the bay, whereas Ni concentration measured in urchin intestines from the same stations only differed by a factor of 4. However, compared to the elevated concentrations of Ni reported in sediments from Honolua Bay (up to $481 \mu \mathrm{g}^{-1}$ dry wt at Hon 1), the Ni concentrations reported in urchin tissues (< $\left.2.9 \mu \mathrm{g} \mathrm{g}^{-1} \mathrm{dwt}\right)$, and alga $\left(<3.9 \mu \mathrm{g} \mathrm{g}^{-1} \mathrm{dwt}\right)$ were low. These concentrations are also low compared to concentrations of $\mathrm{Ni}$ measured in reef organisms living in areas highly impacted by $\mathrm{Ni}$ mining. For example, in the New Caledonia lagoon, concentrations of Ni reached $99.7 \mu \mathrm{g} \mathrm{Ni}$ $\mathrm{g}^{-1} \mathrm{dwt}$ in the digestive gland of the clam Gafrarium tumidum in a site with $797 \mu \mathrm{g} \mathrm{g}^{-1} \mathrm{dwt}$ of Ni in sediments (Hédouin et al. 2008a) and $125 \mu \mathrm{g} \mathrm{Ni} \mathrm{g} \mathrm{g}^{-1} \mathrm{dwt}$ in the alga Lobophora variegata living in a site with $900 \mu \mathrm{g} \mathrm{g}^{-1} \mathrm{dwt}$ of $\mathrm{Ni}$ in sediments (Hédouin et al. 2008a, Hédouin et al. 2008b). These studies demonstrate that high Ni concentrations are measurable in marine tropical organisms when $\mathrm{Ni}$ is present in a bioavailable form. As such, data presented for the reef organisms in Honolua Bay collectively suggest that despite high concentration of $\mathrm{Ni}$ in sediments of Honolua Bay, Ni is bound in the sediments in a chemically inert form that is not bioavailable for the selected reef organisms in the present study.

In contrast to $\mathrm{Ni}, \mathrm{Mn}$ concentrations were found in relatively equal proportions in the reef sediments and urchins, as confirmed by the significant correlations observed between $\mathrm{Mn}$ concentrations in sediments and the three body compartments of the urchins T. gratilla. For example, Mn concentrations were 7 times higher in sediments sampled at Hon1 than at Hon4, and 3.8 (tissues) to 7 (body wall) times higher in urchins from Hon1 compared to Hon4. This suggests that $\mathrm{Mn}$ is bioavailable in Honolua Bay. The higher concentration of $\mathrm{Mn}$ in algae from Honolua Bay as compared to Honokeana Cove also supports the presence of bioavailable Mn in Honolua Bay. Mn is an essential metal involved in many metabolic processes (Simkiss and 
Taylor 1981) and it is highly bioaccumulated in marine organisms (e.g. Howe et al. 2004). Mn is currently not included in the Sediment Quality Guidelines, probably because it is thought to have low toxicity for marine species of phytoplankton, invertebrates and fish (e.g. ranging from 1.5 $\mathrm{mg}^{-1}$ (5-day $\mathrm{EC}_{50}$ ) for the marine diatom Ditylum brightwellii based on growth inhibition to 300 $\mathrm{mg} \mathrm{l}^{-1}$ (168-h $\mathrm{LC}_{50}$ ) for the softshell clam Mya arenaria, Howe et al. 2004). However, after 7days exposure to $>0.01 \mathrm{mg} \mathrm{l}^{-1} \mathrm{Mn}$, embryos of the yellow crab Cancer anthonyi exhibited reduced survival and hatching (Macdonald et al. 1988), suggesting that early life stages of organisms are sensitive to $\mathrm{Mn}$. This metal has also been reported to induce iron deficiency in some algae, leading to inhibition of chlorophyll synthesis (e.g. blue green alga Anacystis nidulans, Csatorday et al. 1984; green algae Ulothrix minuta and U. fimbriata, Rousch and Sommerfeld 1999). Given that corals rely on the photosynthetic activities of endosymbiotic dinoflagellates for nutrition, the impact of Mn on their biology could have a very negative effect. Further studies are needed that focus on the sensitivity of different life stages of corals to Mn to resolve the potential impact.

With the exception of Mn, the contaminants measured here displayed low bioavailability for reef biota. However, the gradient of metal concentrations observed in sediments from the four stations in Honolua Bay correlated with concentrations of sediment discharge into Honolua Bay from Honolua Stream. This provided the ecological context to examine how different levels of land-based contaminants influences the coral ecology. Interestingly, while stations located in the inner part of the bay were mainly composed of boulder bottom (64 - $78 \%)$, corals were present at all sites, albeit with lower coral cover (10.9 and $13.4 \%$ vs. 17.4 and $26.2 \%$ for inshore and offshore stations, respectively), and lower species diversity (5 vs. 9 species for inshore vs. offshore stations). In addition, a shift in distribution of abundant species was also observed with 
the coral Porites compressa being more abundant in offshore than inshore stations, and

411 Montipora patula more abundant in inshore than offshore stations. Although the inshore stations are rarely included in ecological survey of Honolua Bay, our results are consistent with Torricer

413 et al. (1979), who surveyed corals in close proximity to Honolua Stream and recorded values of

4141.3 to $9.5 \%$. Previous surveys in Honolua Bay have reported differences in coral community 415 structure between North and South Bay. For example, Porites sp. dominate the north reef and 416 sediment resistant Montipora sp. dominate the southern reef (Brown 2004). Interestingly, in our 417 study, P. lobata was the most abundant species (32 - 39\%) in all four stations investigated. This 418 is surprising given that $P$. lobata is reported to have a lower active sediment rejection rate than 419 other species (Stafford-Smith 1993), and in Hawaiian Islands P. lobata is mainly observed in 420 regions of moderate wave actions (Jokiel et al. 2004). These preferences are clearly reflected in 421 the ecology of corals along the South-East fringing reef of Moloka' $\mathrm{i}$, where P. lobata is present 422 in stations close to the reef crest (> 700m from shore) where sediments are mainly composed of gravel and coarse sand (38 to $93 \%$ ), but generally absent in near shore stations where sediments are fine and muddy (up to $44 \%$ of mud) (Hédouin et al. Personal Communication, Rodgers et al. 2005). That said, P. lobata is sometimes found in areas with high sedimentation and/or turbidity (Australia, Ayling and Ayling 1987, Bull 1982; Pandora Reef, Palm Islands, Potts et al. 1985). Piniak (2007) recently identified a possible reason for these inconsistencies in documenting a greater negative impact on the fluorescence yield of $P$. lobata from a short-term sedimentation event $(<30 \mathrm{~h})$ of 1,500 to $2,800 \mathrm{mg} \mathrm{cm}^{-2}$ composed of terrigenous sediments than the same 430 sedimentation event with carbonate sand. These data indicate that $P$. lobata, is more sensitive to 431 terrigenous fine particle of sediments than to coarse sand. This may explain why $P$. lobata is 432 observed in the inner sites at Honolua Bay (Hon1 and 3), where coarse sand sediments are 
present (48 - $64 \%$ of coarse sand, Hédouin et al. 2009). Finally, the coral cover in the four stations selected in Honolua Bay reflected the gradient of contaminant concentration observed in the Bay, with significant correlation observed for $\mathrm{Co}, \mathrm{Cr}, \mathrm{Mn}, \mathrm{Ni}, \mathrm{V}$ and $\mathrm{Zn}$. However, since most of these contaminants (with the exception of $\mathrm{Mn}$ ) are not bioavailable for the marine organisms assessed in this study, these correlations likely reflect the complex mixture of landbased contamination stressors (e.g. increasing turbidity, decreasing salinity) discharged from Honolua Stream during rainfall events (as during the event recorded on September $18^{\text {th }}, 2008$ ) rather than metal stress alone. In the context of the low metal bioavailability in sediments for the reef organisms, metal concentrations in sediments appears more useful as a proxy of the landbased contamination present at each site.

\section{CONCluSion}

The sediments in the inshore stations in Honolua Bay displayed very high concentrations of metals and a metalloid, but the concentrations of most of these compounds measured in reef biota (alga, goatfish and urchins) are comparable to concentrations observed in noncontaminated areas (Tables 4, 5). This suggests that with the exception of Mn, the contaminants present in the marine environment of Honolua Bay exhibit low bioavailablility for reef biota. The data demonstrate that the bioavailability of metals and metalloid in Honolua Bay is different depending on the element under consideration. For example, $\mathrm{Mn}$ is more bioavailable than $\mathrm{Ni}$ even though the gradients of metal concentrations observed in sediments for these two elements were relatively similar. Nevertheless, given that the bioavailability of metals in marine organisms is influenced by physical and chemical condition such as $\mathrm{pH}$ and temperature, the bioavailability of these contaminants may change in the context of global warming in the future. In addition, further works should focus on assessing the bioaccumulation and effects of contaminants on 
456 Scleractinian corals present in Honolua Bay, since the sensitivity of corals may be different from

457 the other organisms selected in this study. The high concentration of sediment associated metal 458 and metalloid concentrations highlight the influence of Honolua Stream in discharging sediments 459 into Honolua Bay. Other chemical materials associated with agriculture, such as pesticides, that 460 were not measured here are also likely to be associated with these sediments and to contribute to 461 the complex mixture of threats facing the corals of Honolua Bay. Alleviating local stress level by 462 reducing sediment discharges into Honolua Bay is a feasible and direct management action that 463 has the potential to help coral reefs better face global stressors that are less easy to ameliorate. 464 Such activity has thus the potential to contribute significantly to the conservation of coral reef 465 ecosystem of Honolua Bay.

\section{Acknowledgement}

This work was funded by the Coral Reef Land-Based Pollution Local Action Strategy of Hawai'i. The authors thank Dr K Chaston for her constant support and help in the field, Dr L

471 Guidi for providing the map of West Maui, DA Gulko and the Department of Land and Natural 472 Resources for permits, and Maui DAR personal R Sparks, KK Wong, JK Mitchell and S Hau for 473 their help in catching the goatfishes in Honolua Bay. This work is Hawaii Institute of Marine 474 Biology Contribution Number 3333. 


\section{Bibliography}

Abdallah A, Abdallah M and Beltagy A (2005). Contents of heavy metals in marine seaweeds from the Egyptian coast of the Red Sea. Chemistry and Ecology 21(5), 399-411.

Ablanedo N, Gonzales H, Ramirez M and Torres I (1990). Evaluacion del erizo de mar

Echinometra lucunter como indicator de contaminacion por metales pesades, Cuba (In Spanish). Aquatic Living Resources 3, 113-120.

Al-Shwafi NA and Rushdi AI (2008). Heavy metal concentrations in marine green, brown, and red seaweeds from coastal waters of Yemen, the Gulf of Aden. Environmental Geology 55(3), 653-660.

Andrews S and Sutherland RA (2004). Cu, Pb and $\mathrm{Zn}$ contamination in Nuuanu watershed, Oahu, Hawaii. Science of the Total Environment 324(1-3), 173-182.

Augier H, Ramonda G, Rolland J and Santimone M (1989). Teneurs en métaux lourds des oursins comestibles Paracentrotus lividus (Lamarck) prélevés dans quatre secteurs tests du littoral de Marseille (Méditerranée, France). Vie Marine HS 10, 226-239.

Ayling TA and Ayling AL (1987). Is silt run-off affecting coral communities on the Cape Tribulation fringing reefs? Baldwin CL (ed), Great Barrier Reef Marine Park Authority, Townsville, Queensland

Bohn A (1979). Trace metals in fucoid algae and purple sea urchin near a high artic lead/zinc ore deposit. Marine Pollution Bulletin 10, 325-327.

Boyden CR (1977). Effect of size upon metal content of shellfish. Journal of the Marine Biological Association of the United Kingdom 57, 675-714.

Brown BE and Holley MC (1982). Metal levels associated with tin dredging and smelting and their effect upon intertidal reef flats at Ko Phuket, Thailand. Coral Reefs 1(2), 131-137. 
Brown E (2004). Reef coral population: Spatial and temporal differences observed on six reef off

501 West Maui, University of Hawaii, Honolulu, 277 p.

502 Bryant D, Burke L, McManus J and Spalding M (1998). Reefs at Risk: A map-based indicator of 503 threats to the world's coral reefs, World Resources Institute, Available at

504 http://www.wri.org/publication/reefs-risk-map-based-indicator-potential-threats-worlds-coral-

505 reefs, Washington, D.C

506 Buchanan J, Brown B, Coobs T, Pirie B and Allen J (1980). The accumulation of ferric iron in 507 the gut of some Spatangoid echinoderms. Journal of the Marine Biological Association of the 508 United Kingdom 60, 631-640.

509 Bull GD (1982). Scleractinian coral communities of two inshore high island fringing reefs at 510 Magnetic Island, North Queensland. Marine Ecology Progress Series 7, 267-272.

511 Callahan MA, Slimak MW, Gabel NW, May IP, Fowler CF, Freed JR, Jennings RL, Durfee RL, 512 Whitmore B, Maestri B, Mabey WR, Holt BR and Gould C (1979). Water-related Environmental 513 Fate of 129 Priority Pollutants, Vol. I: Introduction and Technical Background, Metals and 514 Inorganics, Pesticides and PCBs, U.S. Environmental Protection Agency Report EPA-440/4-79515 029a. U.S.E.P.A. Office of Water and Waste Management (ed), Office of Water Planning and 516 Standards, Office of Water and Waste Management, Washington, DC.

517 CEPA (1994). Nickel and its compounds, Goverment of Canada, Ottawa, Canada

518 Chapman PM (2007). Determining when contamination is pollution - Weight of evidence 519 determinations for sediments and effluents. Environment International 33, 492-501.

520 Cossa D, Bourget E and Piuze J (1979). Sexual maturation as a source of variation in the 521 relationship between cadmium concentration and the body weight of the Mytilus edulis L. 522 Marine Pollution Bulletin 10, 174-178. 
CRAMP (2004). Coral Reef Assessment and Monitoring Program Hawaii-Honolua Bay Csatorday K, Gombos Z and Szalontai B (1984). $\mathrm{Mn}^{2+}$ and $\mathrm{Co}^{2+}$ toxicity in chlorophyll biosynthesis. Cell Biology 81, 476-478.

David CP (2003). Heavy metal concentrations in growth bands of corals: a record of mine tailings input through time (Marinduque Island, Philippines). Marine Pollution Bulletin 46(2), 187-196.

De Carlo EH, Tomlinson MS and Anthony SS (2005). Trace elements in streambed sediments of small subtropical streams on O'ahu, Hawai'i: Results from the USGS NAWQA program. Applied Geochemistry 20(12), 2157-2188.

Deheyn DD, Gendreau P, Baldwin RJ and Latz MI (2005). Evidence for enhanced bioavailability of trace elements in the marine ecosystem of Deception Island, a volcano in Antarctica. Marine Environmental Research 60(1), 1-33.

Deudero S, Box A, March D, Valencia JM, Grau AM, Tintore J and Benedicto J (2007). Temporal trends of metals in benthic invertebrate species from the Balearic Islands, Western Mediterranean. Marine Pollution Bulletin 54(9), 1545-1558.

Dolgushina IV, Maksimova OV and Saenko GN (1995). Marine vegetation of the Seychelles Islands and accumulation of trace elements. Oceanology 35(2), 226-231.

Eisler R (1981). Trace metal concentrations in marine organisms, Pergamon Press, New York, $687 \mathrm{p}$.

El-Naggar MEE and Al-Amoudi AA (1989). Heavy metal levels in several species of marine algae from the Red Sea of Saudi Arabia. Journal of King Abdul Aziz University (Science) 1, 513. 
Flammang P, Warnau M, Temara A, Lane DJW and Jangoux M (1997). Heavy metals in Diadema setosum (Echinodermata, Echinoidea) from Singapore coral reefs. Journal of Sea Research 38, 35-45.

Fontaine RA (2003). Availability and distribution of base flow in lower Honokohau Stream, Island of Maui, U.S. Geological Suvey, Honolulu, Hawaii

GESAMP (1984). Review of potentially harmful substances: cadmium, lead and tin, WHO,

Geneva

Guillou M, Quiniou F, Huart B and Pagano G (2000). Comparison of embryonic development and metal contamination in several populations of the sea urchin Sphaerechinus granularis (Lamarck) exposed to anthropogenic pollution. Archives of Environmental Contamination and Toxicology 39(3), 337-344.

Hanna RG and Muir GL (1990). Red Sea corals as biomonitors of trace metal pollution. Environmental Monitoring and Assessment 14(2-3), 211-222.

Hédouin L, Bustamante P, Churlaud C, Pringault O, Fichez R and Warnau M (2008a). Trends in concentrations of selected metalloid and metals in two bivalves from the coral reefs in the SW lagoon of New Caledonia. Ecotoxicology and Environmental Safety 72, 372-381.

Hédouin L, Bustamante P, Fichez R and Warnau M (2008b). The tropical brown alga Lobophora variegata as a bioindicator of mining contamination in the New Caledonia lagoon: a field transplantation study. Marine Environmental Research 66(4), 438-444.

Hédouin L, Reichelt-Brushett AJ and Gates RD (2009). Assessment of metals and a metalloid in sediments from Hawaiian coral reef ecosystems. Marine Pollution Bulletin 58, 1739-1765.

Hédouin L, Vargas-Ángel B, Reichelt-Brushett AJ, Pochon X and Gates RD (Personal Communication). Multi-scale approach for assessing the effects of land-based contamination on 

the Southeast fringing reef of Molokai. 11th International Coral Reef Symposium (ICRS) Conference (ed), 7-11 Juillet 2008, Fort Lauderdale, Florida (United States)

Hill J and Wilkinson C (2004). Methods for ecological monitoring of coral reefs : A resource for managers. Version 1., Townsville, Australia, 117 p.

Hoegh-Guldberg O, Mumby PJ, Hooten AJ, Steneck RS, Greenfield P, Gomez E, Harvell CD, Sale PF, Edwards AJ, Caldeira K, Knowlton N, Eakin CM, Iglesias-Prieto R, Muthiga N, Bradbury RH, Dubi A and Hatziolos ME (2007). Coral reefs under rapid climate change and ocean acidification. Science 318, 1737-1742.

Hornik, Kurt (2010). The R FAQ. ISBN 3-900051-08-9; http://CRAN.R-project.org/doc/FAQ/RFAQ.html

Howe PD, Malcolm HM and Dobson S (2004). Manganese and its compounds: Environmental aspects. Organization WH (ed), Geneva

Hunter CL, Stephenson MD, Tjeerdema RS, Crosby DG, Ichikawa GS, Goetzl JD, Paulson KS, Crane DB, Martin M and Newman JW (1995). Contaminants in oysters in Kaneohe Bay, Hawaii. Marine Pollution Bulletin 30(10), 646-654.

Jokiel P, Brown E, Friedlander A, Rodgers S and Smith W (2004). Hawaii Coral Reef Assessment and Monitoring Program: Spatial patterns and temporal dynamics in reef coral communities Pacific Science 58(2), 159-174.

Kabata-Pendias A (2001). Trace elements in soils and plants, Boca Raton, 432 p.

Khristoforova NK and Bogdanova NN (1980). Mineral composition of seaweeds from coral Islands of the Pacific Ocean as a function of environmental conditions. Marine Ecology Progress Series 3, 25-29. 
Long ER, Macdonald DD, Smith SL and Calder FD (1995). Incidence of adverse biological effect within ranges of chemical concentrations in marine and estuarine sediments. Environmental Management 19(1), 81-97.

Macdonald JM, Shields JD and Zimmer-Faust RK (1988). Acute toxicities of eleven metals to early life-history stages of the yellow crab Cancer anthonyi. Marine Biology 98(2), 201-207. Marine Research Consultants Inc (2007). An assessment of the marine environment in the 596 vicinity of Lipoa Point, Kapalau, West Maui, Hawaii

597 McMurtry GM, Wiltshire JC and Kauahikaua JP (1995). Heavy metal anomalies in coastal 598 sediments of Oahu, Hawaii. Pacific Science 49(4), 452-470.

599 Miao X-S, Ann Woodward L, Swenson C and Li QX (2001). Comparative concentrations of 600 metals in marine species from French Frigate Shoals, North Pacific Ocean. Marine Pollution 601 Bulletin 42(11), 1049-1054.

602 Moore NW (1966). A pesticide monitoring system with special reference to the selection of 603 indicator species. Journal of Applied Ecology 3, 261-269.

604 Naidenko T (1997). Abnormality of development in Strongylocentrotus intermedius (A. Agassiz) 605 larvae from polluted habitat in Amursky Bay, Peter the Great Bay. Publications of the Seto 606 Marine Biological Laboratory 38, 1-11.

607 Negri AP, Smith LD, Webster NS and Heyward AJ (2002). Understanding ship-grounding 608 impacts on a coral reef: potential effects of anti-foulant paint contamination on coral recruitment. 609 Marine Pollution Bulletin 44(2), 111-117.

610 NOAA (1999). Screening Quick Reference Tables (Squirts), Hazmat Report 
611 Parham JE, Higashi GR, Lapp EK, Kuamo’o DGK, Nishimoto RT, Hau S, Fitzsimons JM,

612 Polhemus DA and Devick WS (2008). Atlas of Hawaiian Watersheds \& Their Aquatic

613 Resources, Island of Maui, Bishop Museum \& Division of Aquatic Resources, 866 p.

614 Phillips DJH (1990). Heavy metals in the marine environment. Furness RW and Rainbow PS 615 (eds), pp. 81-99, CRC Press, Boca Raton.

616 Piniak GA (2007). Effects of two sediment types on the fluorescence yield of two Hawaiian 617 scleractinian corals. Marine Environmental Research 64(4), 456-468.

618 Potts DC, Done TJ, Isdale PJ and Fisk DA (1985). Dominance of a coral community by the 619 genus Porites (Scleractinia). Marine Ecology Progress Series 23, 79-84.

620 Prudente M, Kim E-Y, Tanabe S and Tatsukawa R (1997). Metal levels in some commercial fish 621 species from Manila Bay, the Philippines. Marine Pollution Bulletin 34(8), 671-674.

622 Richmond RH (1993). Coral reefs: Present problems and future concerns resulting from 623 anthropogenic disturbance. American Zoologist 33, 524-536.

624 Riley JP and Segar DA (1970). The distribution of the major and some minor elements in marine 625 animals. I. Echinoderms and coelenterates. Journal of the Marine Biological Association of the 626 United Kingdom 50, 721-730.

627 Rodgers KS, Jokiel PL, Smith WR, Farrell F and Uchino K (2005). Biological survey in support 628 of the USGS turbidity and sediment baseline survey on south Moloka'i reef flat, April 2005. 629 Survey USG (ed)

630 Roméo M, Siau Y, Sidoumou Z and Gnassia-Barelli M (1999). Heavy metal distribution in 631 different fish species from the Mauritania coast. Science of the Total Environment 232(3), 169632175. 
633

634

635

636

637

638

639

640

641

642

643

644

645

646

647

648

649

650

651

652

653

654

655

Rousch JM and Sommerfeld MR (1999). Effect of manganese and nickel on growth of selected algae in pH buffered medium. Water Research 33(10), 2448-2454.

Salomons W and Forstner U (1984). Metals in the hydrocycle, Berlin 349 p.

Salomons W, de Rooij NM, Derdijk H and Bril J (1987). Sediments as a source for contaminants? Hydrobiologia 149, 13-30.

Sawidis T, Brown MT, Zachariadis G and Sratis I (2001). Trace metal concentrations in marine macroalgae from different biotopes in the Aegean Sea. Environment International 27(1), 43-47.

Scott PJB and Davies GB (1997). Retroactive determination of industrial contaminants in tropical marine communities. Marine Pollution Bulletin 34(11), 975-980.

Shiber JG (1980). Trace metals with seasonal considerations in coastal algae and molluscs from Beirut, Lebanon. Hydrobiologia 69(1-2), 147-162.

Simkiss K and Taylor M (1981). Cellular mechanisms of metal ion detoxification and some new indices of pollution. Aquatic Toxicology 1(5-6), 279-290.

Snodgrass WJ (1980). Nickel in the Environment. Nriagu JO (ed), pp. 203-274, John Wiley and Sons, New York.

Stafford-Smith MG (1993). Sediment-rejection efficiency of 22 species of Australian scleractinian corals. Marine Biology 115(2), 229-243.

Storelli MM, Storelli A and Marcotrigiano GO (2001). Heavy metals in the aquatic environment of the Southern Adriatic Sea, Italy: Macroalgae, sediments and benthic species. Environment International 26(7-8), 505-509.

Storlazzi CD and Jaffe BE (2003). Coastal circulation and sediment dynamics along West Maui, Hawaii. PART I: Long-term measurements of currents, temperature, salinity and turbidity off Kahana, West Maui: 2001-2003. Survey USG (ed), Santa Cruz, California 
Storlazzi CD, Field ME, Ogston AS, Logan JB, Presto MK and Gonzales DG (2004). Coastal

657

658

659

660

661

662

663

664

665

666

667

668

669

670

671

672

673

674

675

676

677 circulation and sediment dynamics along West Maui, Hawaii. PART III: Flow and particulate dynamics during the 2003 summer coral spawning season. Survey USG (ed), Santa Cruz, California

Storlazzi CD and Presto MK (2005). Coastal circulation and sediment dynamics along West Maui, Hawaii. PART IV: Measurements of waves, currents, temperature, salinity and turbidity in Honolua Bay, Northwest Maui: 2003-2004 Survey USG (ed), Santa Cruz, California

Torricer L, Akita G, Anzai GA, L. B, Fantine R, Kobayashi T, Muraoka G, Price H and Takenaka S (1979). Marine Option Program data acquisition project: Honolua Bay, Maui. 1979:

Honolulu, Sea Grant College Program, University of Hawai i, Honolulu

Warnau M, Ledent G, Temara A, Bouquegneau J-M, Jangoux M and Dubois P (1995). Heavy metals in Posidonia oceanica and Paracentrotus lividus from seagrass beds of the north-western Mediterranean. Science of the Total Environment 171, 95-99.

Warnau M (1996). Valeur bioindicative des adultes et effets des contaminations métalliques sur les stades prémétamorphiques de l'échinide Paracentrotus lividus, espèce-clé des herbiers à Posidonia oceanica de méditérranée, Université Libre de Bruxelles, Bruxelles, Belgium, 161 p.

Warnau M, Biondo R, Temara A, Bouquegneau J-M, Jangoux M and Dubois P (1998). Distribution of heavy metals in the echinoid Paracentrotus lividus from the Mediterranean Posidonia oceanica ecosystem: seasonal and geographical variations. Journal of Sea Research $39(3-4), 267-280$.

Wilkinson CR (1999). Global and local threats to coral reef functioning and existence: Review and predictions. Marine and Freshwater research 50, 867-878. 
678 Zar JH (1996). Biostatistical analysis, Prenctice hall College Div.; 3rd Edition, Upper Saddle 679 River, New Jersey, 662 p.

680

681 
Figure 1. Selected sampling locations for reef sediments, the alga Halimeda kanaloana, the goatfish Parupeneus multifasciatus and the urchin Tripneustes gratilla, along the West coast of Maui, Hawaii

Figure 2. Comparisons of element concentrations in (A) sediment collected (A1) inside and (A2) inside and outside Honolua Bay, using multiple comparison test of Tukey performed after one-way ANOVA, and (B) the urchin Tripneustes gratilla using multiple comparison test of Tukey performed after two-way ANOVA (B1, Geographical variation; B2, Body compartment). Mean concentrations are ranked from the left to the right by decreasing order. Concentrations in underlined body compartments or stations are not significantly different $(\alpha=0.05)$.

Body compartments: Intestinal tissues (I), Gonad (G), Body wall (B)

Sampling locations: Honolua 1 (Hon1), Honolua 2 (Hon2), Honolua 3 (Hon3), Honolua 4 (Hon4), Honokeana Cove (HC), Lipoa Point (LP), Kapalua Beach (KB), Honokohau Bay (HB) and Mokulei'a Bay (MB)

Figure 3. Element concentrations in three body compartments of the urchin Tripneustes gratilla (intestine, gonads and carapace) as a function of their respective element concentrations in sediments. (“*” indicate that the significant correlation was observed between metal concentration in urchin body compartments and those in sediments; $* p<0.05, * * p<0.01$, $* * * \mathrm{p}<0.001, * * * * \mathrm{p}<0.001)$

Figure 4. Ecological parameters of four stations in Honolua Bay. (A) Percent distribution of various bottom types (Live coral, dead coral, boulder bottom, alga, sand and reef bed); (B) 
Percentage (Distribution frequency) of coral colonies measured at each station; (C) Percent distribution of coral colors (Healthy; Pale, Partially bleached, Bleached); (D) Average colony diameters for the five most abundant coral species (Mean \pm S.D.); (E) Percentage of mortality of the five most abundant coral species.

Species codes: Porites lobata (PLOB), Porites compressa (PCOM), Montipora capitata (MCAP), Montipora patula (MPAT), Pocillopora meandrina (PMEA)

Station codes: Honolua 1 (Hon1), Honolua 2 (Hon2), Honolua 3 (Hon3), Honolua 4 (Hon4)

Figure 5. Linear regressions of mean live coral cover versus metal concentration. Mean total coral cover vs. (A) Co and (B) V concentration in sediments, all stations. Coefficient of determination and significance shown only for significant regressions.

Figure 6. Turbidity (Mean \pm S.D.) (A) and temperature (B) of seawater at the four stations in Honolua Bay over time. A rain event occurred on September $18^{\text {th }}, 2007$.

Station codes: Honolua 1 (Hon1), Honolua 2 (Hon2), Honolua 3 (Hon3), Honolua 4 (Hon4) 
Metal and metalloid levels in sediments and tropical organisms from West Maui. Ecological surveys of corals in Honolua Bay.

Elevated levels of $\mathrm{Co}, \mathrm{Cr}, \mathrm{Mn}, \mathrm{Ni}$ and $\mathrm{V}$ in reef sediments.

Low bioavailability of contaminants for organisms.

Correlations between coral cover and $\mathrm{Co}, \mathrm{Cr}, \mathrm{Mn}, \mathrm{Ni}, \mathrm{V}, \mathrm{Zn}$ levels in sediments. 


\begin{tabular}{|c|c|c|c|c|c|c|c|c|c|c|}
\hline Sites & $\begin{array}{c}\text { As } \\
\mathrm{m} \pm \text { S.D. }\end{array}$ & $\begin{array}{c}\text { Co } \\
\mathrm{m} \pm \text { S.D. }\end{array}$ & $\begin{array}{c}\mathbf{C r} \\
\mathrm{m} \pm \text { S.D. }\end{array}$ & $\begin{array}{c}\mathbf{C u} \\
\mathrm{m} \pm \text { S.D. }\end{array}$ & $\begin{array}{c}\mathbf{F e} \\
\mathrm{m} \pm \text { S.D. }\end{array}$ & $\begin{array}{c}\text { Mn } \\
\mathrm{m} \pm \text { S.D. }\end{array}$ & $\begin{array}{c}\mathbf{N i} \\
\mathrm{m} \pm \text { S.D. }\end{array}$ & $\begin{array}{c}\mathbf{P b} \\
\mathrm{m} \pm \text { S.D. }\end{array}$ & $\begin{array}{c}\mathbf{V} \\
\mathrm{m} \pm \text { S.D. }\end{array}$ & $\begin{array}{c}\mathbf{Z n} \\
\mathrm{m} \pm \text { S.D. }\end{array}$ \\
\hline Honolua 1 & $39.2 \pm 4.8^{b}$ & $48.4 \pm 7.3$ & $95.9 \pm 12.0^{b}$ & $13.9 \pm 2.5$ & $7013 \pm 175$ & $594.4 \pm 49.8$ & $481.3 \pm 62.1^{\mathrm{c}}$ & $36.2 \pm 4.6^{\mathrm{a}}$ & $346.1 \pm 48.3$ & $54.9 \pm 4.4$ \\
\hline Honolua 2 & $34.3 \pm 2.3^{b}$ & $16.9 \pm 2.5$ & $40.7 \pm 5.4$ & $7.08 \pm 1.34$ & $7023 \pm 171$ & $249.8 \pm 26.4$ & $151.4 \pm 34.8^{c}$ & $19.0 \pm 3.3$ & $179.5 \pm 26.3$ & $20 . \pm 2.0$ \\
\hline Honolua 3 & $42.5 \pm 1.5^{b}$ & $36.6 \pm 1.2$ & $93.5 \pm 4.3^{b}$ & $17.1 \pm 1.3$ & $7018 \pm 172$ & $375.8 \pm 12.2$ & $302.8 \pm 16.5^{c}$ & $34.7 \pm 4.5^{\mathrm{a}}$ & $269.7 \pm 12.9$ & $47.8 \pm 1.8$ \\
\hline Honolua 4 & $24.0 \pm 0.3^{b}$ & $2.71 \pm 0.4$ & $13.9 \pm 1.0$ & $5.25 \pm 0.88$ & $3253 \pm 247$ & $84.6 \pm 10.3$ & $9.93 \pm 1.35$ & $14.6 \pm 16.7$ & $89.4 \pm 10.0$ & $6.52 \pm 0.67$ \\
\hline Hokuanui bay & $34.8 \pm 3.2^{b}$ & $3.61 \pm 0.61$ & $16.7 \pm 0.4$ & $6.00 \pm 0.24$ & $5131 \pm 962$ & $135.4 \pm 16.8$ & $17.7 \pm 3.7^{\mathrm{a}}$ & $17.6 \pm 0.6$ & $108.3 \pm 7.6$ & $10.7 \pm 2.2$ \\
\hline Honokeana cove & $27.01 \pm 0.4^{\mathrm{b}}$ & $5.41 \pm 0.5$ & $21.3 \pm 1.0$ & $7.54 \pm 0.24$ & $6828 \pm 5$ & $168.4 \pm 8.9$ & $22.6 \pm 2.4^{b}$ & $20.7 \pm 0.7$ & $103.2 \pm 4.4$ & $16.7 \pm 2.5$ \\
\hline Lipoa point & $25.7 \pm 0.5^{b}$ & $2.65 \pm 0.2$ & $14.7 \pm 0.9$ & $6.09 \pm 0.45$ & $3259 \pm 251$ & $91.1 \pm 11.6$ & $10.31 \pm 1.71$ & $15.9 \pm 0.8$ & $94.4 \pm 3.8$ & $6.7 \pm 0.61$ \\
\hline Honokohau bay & $56.2 \pm 1.4^{b}$ & $45.5 \pm 3.2$ & $73.1 \pm 5.1^{\mathrm{a}}$ & $17.1 \pm 1.0$ & $7016 \pm 169$ & $491.7 \pm 21.0$ & $373.9 \pm 43.9^{c}$ & $35.3 \pm 1.7^{\mathrm{a}}$ & $343.0 \pm 27.0$ & $51.2 \pm 2.1$ \\
\hline Mokulei'a bay & $48.1 \pm 1.4^{b}$ & $19.9 \pm 2.1$ & $47.3 \pm 5.7$ & $9.39 \pm 0.66$ & $6836 \pm 8$ & $296.5 \pm 15.3$ & $144.6 \pm 28.4^{c}$ & $26.1 \pm 0.9$ & $190.6 \pm 13.1$ & $25.1 \pm 2.4$ \\
\hline TEL & 7.24 & & 52.3 & 18.7 & & & 15.9 & 30.24 & & 124.0 \\
\hline ERL & 8.2 & & 81 & 34 & & & 20.9 & 46.7 & & 150.0 \\
\hline ERM & 70 & & 370 & 270 & & & 51.6 & 218 & & 410.0 \\
\hline
\end{tabular}

Table 1. Metal and metalloid concentrations in superficial reef sediments collected from 9 sites in West Maui, and values of the Sediment Quality Guidelines. TEL: Threshold Effect Level; ERL: Effect-Range Low; ERM: Effect-Range Median based on NOAA sediment quality guideline (Long et al. 1995) and NOAA Screening Quick Reference Tables (NOAA 1999).

${ }^{\mathrm{a}}$ indicated that the element concentration is superior to the TEL, ${ }^{\mathrm{b}}$ to the ERL, and ${ }^{\mathrm{c}}$ to the ERM. 


\begin{tabular}{|c|c|c|c|c|c|c|c|c|c|c|c|}
\hline Species & Sites & $\begin{array}{c}\text { As } \\
\mathrm{m} \pm \text { S.D. }\end{array}$ & $\begin{array}{c}\text { Co } \\
\mathrm{m} \pm \text { S.D. }\end{array}$ & $\begin{array}{c}\mathbf{C r} \\
\mathrm{m} \pm \text { S.D. }\end{array}$ & $\begin{array}{c}\mathbf{C u} \\
\mathrm{m} \pm \text { S.D. }\end{array}$ & $\begin{array}{c}\mathbf{F e} \\
\mathrm{m} \pm \text { S.D. }\end{array}$ & $\begin{array}{c}\text { Mn } \\
\mathrm{m} \pm \text { S.D. }\end{array}$ & $\begin{array}{c}\mathbf{N i} \\
\mathrm{m} \pm \text { S.D. }\end{array}$ & $\begin{array}{c}\mathbf{P b} \\
\mathrm{m} \pm \text { S.D. }\end{array}$ & $\begin{array}{c}\mathbf{V} \\
\mathrm{m} \pm \text { S.D. }\end{array}$ & $\begin{array}{c}\mathbf{Z n} \\
\mathrm{m} \pm \text { S.D. }\end{array}$ \\
\hline \multirow{16}{*}{ T. gratilla } & & & & & & Gonads & & & & & \\
\hline & Honolua 1 & $17.6 \pm 4.7$ & $1.41 \pm 0.29$ & $5.05 \pm 1.93$ & $3.34 \pm 0.63$ & $239 \pm 121$ & $14.2 \pm 5.4$ & $2.47 \pm 1.35$ & $6.06 \pm 0.91$ & $37.8 \pm 8.3$ & $52.8 \pm 24.3$ \\
\hline & Honolua 4 & $14.8 \pm 4.7$ & $1.05 \pm 0.65$ & $7.99 \pm 1.88$ & $4.53 \pm 0.86$ & $202 \pm 131$ & $3.64 \pm 2.16$ & $2.23 \pm 0.57$ & $9.16 \pm 2.10$ & $47.0 \pm 15.1$ & $25.4 \pm 9.1$ \\
\hline & Kapalua & $15.1 \pm 2.4$ & $0.53 \pm 0.26$ & $2.38 \pm 0.95$ & $2.14 \pm 0.83$ & $65.4 \pm 24.1$ & $2.83 \pm 2.57$ & $0.87 \pm 0.25$ & $2.93 \pm 1.95$ & $48.0 \pm 24.2$ & $28.0 \pm 23.6$ \\
\hline & Honokeana & $9.74 \pm 3.43$ & $0.70 \pm 0.84$ & $1.75 \pm 0.71$ & $2.26 \pm 0.65$ & $42.0 \pm 18.0$ & $3.89 \pm 2.03$ & $0.58 \pm 0.19$ & $3.21 \pm 1.35$ & $24.2 \pm 5.2$ & $30.7 \pm 12.2$ \\
\hline & Lipoa Point & $14.6 \pm 2.8$ & $0.94 \pm 0.06$ & $2.95 \pm 0.60$ & $3.19 \pm 1.11$ & $52.9 \pm 34.6$ & $4.26 \pm 2.58$ & $0.98 \pm 0.09$ & $5.04 \pm 0.33$ & $36.1 \pm 15.0$ & $28.3 \pm 12.1$ \\
\hline & Honolua 1 & $80.3 \pm 17.8$ & $2.33 \pm 0.54$ & $3.36 \pm 0.86$ & $7.66 \pm 1.05$ & $\begin{array}{l}\text { Intestine } \\
946 \pm 163\end{array}$ & $28.9 \pm 9.3$ & $2.82 \pm 0.92$ & $6.83 \pm 0.77$ & $26.0 \pm 6.1$ & $36.3 \pm 5.1$ \\
\hline & Honolua 4 & $37.1 \pm 5.3$ & $1.35 \pm 0.57$ & $4.04 \pm 1.77$ & $7.30 \pm 1.23$ & $625 \pm 82.4$ & $7.54 \pm 1.58$ & $2.80 \pm 0.88$ & $7.20 \pm 1.45$ & $27.7 \pm 3.9$ & $43.2 \pm 11.4$ \\
\hline & Kapalua & $38.7 \pm 11.5$ & $1.06 \pm 0.08$ & $2.50 \pm 0.70$ & $4.94 \pm 1.75$ & $738 \pm 210$ & $8.80 \pm 1.00$ & $1.60 \pm 1.67$ & $5.65 \pm 0.46$ & $35.1 \pm 8.0$ & $38.0 \pm 8.7$ \\
\hline & Honokeana & $40.0 \pm 6.9$ & $0.55 \pm 0.45$ & $1.14 \pm 1.17$ & $5.96 \pm 0.85$ & $1096 \pm 413$ & $16.0 \pm 5.7$ & $1.22 \pm 0.44$ & $5.02 \pm 0.59$ & $31.7 \pm 5.8$ & $31.8 \pm 3.9$ \\
\hline & Lipoa Point & $59.6 \pm 19.8$ & $1.33 \pm 0.02$ & $2.97 \pm 0.34$ & $8.86 \pm 1.90$ & $672 \pm 219$ & $12.2 \pm 3.2$ & $2.42 \pm 0.93$ & $6.91 \pm 0.56$ & $32.2 \pm 2.3$ & $43.7 \pm 10.7$ \\
\hline & Honolua 1 & $14.3 \pm 2.8$ & $0.85 \pm 0.29$ & $4.97 \pm 2.14$ & $3.48 \pm 2.02$ & $\begin{array}{l}\text { Body Wall } \\
62.7 \pm 24.7\end{array}$ & $9.03 \pm 3.56$ & $1.28 \pm 0.63$ & $6.61 \pm 4.14$ & $106.7 \pm 7.7$ & $3.28 \pm 1.58$ \\
\hline & Honolua 4 & $15.0 \pm 3.1$ & $0.89 \pm 0.29$ & $5.14 \pm 1.46$ & $3.37 \pm 1.39$ & $22.6 \pm 11.0$ & $1.24 \pm 0.54$ & $1.18 \pm 0.53$ & $7.86 \pm 3.71$ & $103.4 \pm 9.0$ & $2.93 \pm 0.70$ \\
\hline & Kapalua & $17.5 \pm 2.3$ & $1.23 \pm 0.10$ & $6.04 \pm 1.11$ & $4.93 \pm 1.20$ & $29.9 \pm 6.6$ & $2.06 \pm 0.68$ & $1.66 \pm 0.68$ & $13.1 \pm 0.6$ & $111.9 \pm 7.0$ & $2.56 \pm 0.27$ \\
\hline & Honokeana & $14.0 \pm 3.2$ & $1.09 \pm 0.16$ & $4.13 \pm 1.82$ & $2.98 \pm 1.84$ & $13.4 \pm 4.3$ & $2.57 \pm .76$ & $1.05 \pm 0.31$ & $6.05 \pm 5.21$ & $98.5 \pm 7.9$ & $2.72 \pm 0.43$ \\
\hline & Lipoa Point & $14.2 \pm 3.1$ & $0.69 \pm 0.76$ & $4.05 \pm 1.51$ & $2.69 \pm 1.87$ & $10.0 \pm 3.8$ & $2.22 \pm 0.73$ & $0.80 \pm 0.83$ & $5.93 \pm 4.75$ & $104.2 \pm 8.3$ & $2.47 \pm 0.65$ \\
\hline \multirow[t]{2}{*}{ P. multifasciatus } & Honolua & $39.9 \pm 10.7$ & $0.17 \pm 0.11$ & $1.40 \pm 0.47$ & $0.87 \pm 0.24$ & $\begin{array}{c}\text { Muscle } \\
14.8 \pm 6.5 \\
\text { Liver }\end{array}$ & $0.56 \pm 0.34$ & $0.69 \pm 0.46$ & $1.45 \pm 0.44$ & $3.85 \pm 0.86$ & $10.3 \pm 1.9$ \\
\hline & Honolua & $54.8 \pm 27.0$ & $1.98 \pm 0.79$ & $1.44 \pm 1.05$ & $15.6 \pm 3.2$ & $4400 \pm 931$ & $7.42 \pm 1.76$ & $0.53 \pm 0.38$ & $2.89 \pm .89$ & $5.11 \pm 2.38$ & $112 \pm 10.3$ \\
\hline \multirow{2}{*}{ H. kanaloana } & Honolua 5 & $15.8 \pm 5.6$ & $0.92 \pm 0.43$ & $6.24 \pm 2.77$ & $4.02 \pm 1.52$ & $531 \pm 155$ & $12.8 \pm 2.3$ & $3.81 \pm 1.88$ & $8.74 \pm 3.10$ & $23.4 \pm 3.4$ & $2.63 \pm 0.61$ \\
\hline & Honokeana & $16.0 \pm 7.5$ & $1.33 \pm 0.68$ & $7.32 \pm 2.82$ & $4.96 \pm 2.24$ & $374 \pm 74.5$ & $9.86 \pm 0.89$ & $1.97 \pm 1.27$ & $8.52 \pm 5.22$ & $23.2 \pm 15.0$ & $3.09 \pm 1.95$ \\
\hline
\end{tabular}

Table 2. Element concentrations (mean \pm S.D.; $\mu \mathrm{g} \mathrm{g} \mathrm{g}^{-1} \mathrm{dwt}$ ) in the urchin Tripneustes gratilla $(\mathrm{n}=7$ per station, except for Lipoa Point $\mathrm{n}=4)$, the goatfish Parupeneus multifasciatus $(\mathrm{n}=6)$ and the alga Halimeda kanaloana $(\mathrm{n}=7)$ collected in the West Maui 


\begin{tabular}{|c|c|c|c|}
\hline \multicolumn{4}{|c|}{ A) GENERAL } \\
\hline \multicolumn{2}{|c|}{ Factor 1} & Factor 2 & Pearson values \\
\hline \multicolumn{2}{|c|}{ Coral cover } & Co & $-0.972 *$ \\
\hline \multicolumn{2}{|c|}{ Coral cover } & $\mathrm{Cr}$ & $-0.955 *$ \\
\hline \multicolumn{2}{|c|}{ Coral cover } & $\mathrm{Mn}$ & $-0.955 *$ \\
\hline \multicolumn{2}{|c|}{ Coral cover } & $\mathrm{Ni}$ & $-0.960 *$ \\
\hline \multicolumn{2}{|c|}{ Coral cover } & V & $-0.979 *$ \\
\hline \multicolumn{2}{|c|}{ Coral cover } & $\mathrm{Zn}$ & $-0.958 *$ \\
\hline \multicolumn{4}{|c|}{ B) BY CORAL SPECIES } \\
\hline Species & Factor 1 & Factor 2 & Pearson values \\
\hline PLOB & Diameter & As & $-0.964 *$ \\
\hline PLOB & Diameter & $\mathrm{Fe}$ & $-0.976 *$ \\
\hline MPAT & Diameter & $\mathrm{Cu}$ & $-0.976 *$ \\
\hline PCOM & Diameter & Partial mortality & $+0.992 * *$ \\
\hline PCOM & Diameter & Turbidity & $-0.975 *$ \\
\hline
\end{tabular}

Table 3. Results of the Pearson Correlation performed on the different reef health parameters and the element concentration in sediment for A) all species combined and B) for each coral species. Only significant correlations $(<0.05)$ are presented $(*:<0.05 ; * *$ : $<0.01)$

Species codes: Porites lobata (PLOB), Porites compressa (PCOM), Montipora patula (MPAT) 


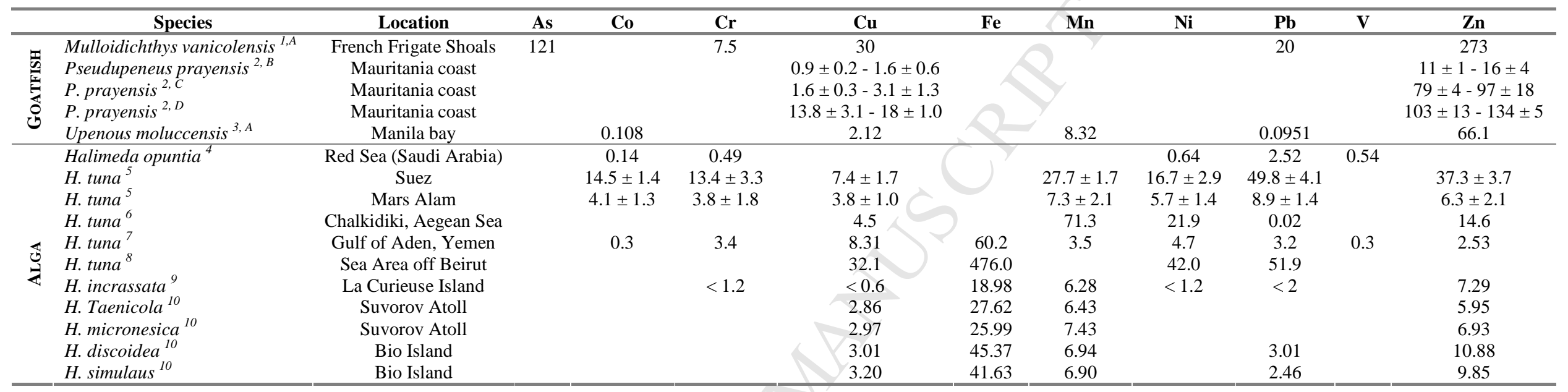

${ }^{1}$ Miao et al. 2001; ${ }^{2}$ Roméo et al. $1999 ;{ }^{3}$ Prudente et al. $1997 ;{ }^{4}$ El-Naggar and Al-Amoudi 1989; ${ }^{5}$ Abdallah et al. $2005 ;{ }^{6}$ Sawidis et al. 2001; ${ }^{7}$ Al-Shwafi and Rushdi $2008 ;{ }^{8}$ Shiber $1980 ;{ }^{9}$ Dolgushina et al. $1995 ;{ }^{10}$ Khristoforova and Bogdanova 1980

${ }^{\mathrm{A}}$ Whole, ${ }^{\mathrm{B}}$ Muscle, ${ }^{\mathrm{C}}$ Gills, ${ }^{\mathrm{D}}$ Liver

Table 4. Element concentrations (mean \pm S.D. or range; $\mu \mathrm{g} \mathrm{g}^{-1} \mathrm{dwt}$ ) in goatfishes and the algae Halimeda sp. from various geographical areas 


\begin{tabular}{|c|c|c|c|c|c|c|c|c|c|c|c|}
\hline Urchin species & Location & Organs & As & $\mathbf{C r}$ & $\mathbf{C u}$ & $\mathbf{F e}$ & Mn & $\mathbf{N i}$ & $\mathbf{P b}$ & $\mathbf{V}$ & Zn \\
\hline Diadema setosum ${ }^{1}$ & Singapore reef & Gonads & & $\begin{array}{l}1.39 \pm 0.99- \\
4.83 \pm 3.57\end{array}$ & $\begin{array}{l}2.91 \pm 0.45- \\
7.73 \pm 7.18\end{array}$ & $\begin{array}{c}88 \pm 77- \\
285 \pm 229\end{array}$ & & & $\begin{array}{c}0.78 \pm 0.29- \\
1.86 \pm 0.65\end{array}$ & & $\begin{array}{r}129 \pm 162- \\
307 \pm 369\end{array}$ \\
\hline D. setosum ${ }^{1}$ & Singapore reef & Body wall & & $\begin{array}{c}0.48 \pm 0.15- \\
1.11 \pm 0.95 \\
\end{array}$ & $\begin{array}{c}0.31 \pm 0.22- \\
1.65 \pm 1.28\end{array}$ & $\begin{array}{c}25 \pm 16- \\
81 \pm 46\end{array}$ & & & $\begin{array}{r}2.48 \pm 0.67- \\
4.24 \pm 1.3 \\
\end{array}$ & & $\begin{array}{r}12.33 \pm 1.17 \\
15.14 \pm 2.18 \\
\end{array}$ \\
\hline D. setosum ${ }^{l}$ & Singapore reef & Skeleton & & $\begin{array}{l}1.18 \pm 0.76- \\
2.22 \pm 0.71\end{array}$ & $\begin{array}{l}0.35 \pm 0.12- \\
1.01 \pm 0.36\end{array}$ & $\begin{array}{c}8 \pm 3- \\
34 \pm 26\end{array}$ & & & $\begin{aligned} & 4.69 \pm 0.85- \\
& 7.4 \pm 2.05\end{aligned}$ & & $\begin{array}{l}4.82 \pm 0.6- \\
6.36 \pm 1.63\end{array}$ \\
\hline Echinocardium cordatum ${ }^{2}$ & Isle of Arran, Scotland & Gonads & & & ( & 184 & & & 4,4 & & 239 \\
\hline E. cordatum ${ }^{2}$ & Isle of Arran, Scotland & Gut & & & 11 & 3480 & & & 5,8 & & 74 \\
\hline Echinus esculentus ${ }^{3}$ & Irish Sea, UK & Oral body wall & & & 1,8 & 6,9 & & & $<0.62$ & & 110 \\
\hline E. esculentus ${ }^{3}$ & Irish Sea, UK & Aboral body wall & & & 0,9 & 2,5 & & & $<0.62$ & & 12 \\
\hline E. esculentus ${ }^{3}$ & Irish Sea, UK & Gonads & & & 16 & 15 & & & $<0.68$ & & 110 \\
\hline Echinometra lucunter & Cuba & Gonads & & & $2.57-6.09$ & $45.8-180$ & & & & & $230-436$ \\
\hline Paracentrotus lividus ${ }^{5+1}$ & Marseille (France) & Body wall & & & $1-5.33$ & & & & $0.3-1.19$ & & \\
\hline P. lividus & Marseille (France) & Gonads & & & $4.02-6.34$ & 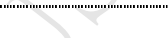 & & & $0.3-3.14$ & & \\
\hline P. lividus ${ }^{6}$ & NW Mediterranean & Gonads & & $0.88-1.59$ & $2.68-3.18$ & $35-101$ & & & $1.38-2.02$ & & $124-161$ \\
\hline P. lividus ${ }^{5}$ & Marseille (France) & Gonads & & & 6,34 & & & & 3,14 & & \\
\hline P. lividus & Marseille (France) & Gut & & & 22,9 & & & & 28,1 & & \\
\hline P. lividus ${ }^{6}$ & NW Mediterranean & Digestive wall & & $\begin{array}{c}0.86 \pm 0.17- \\
1.23 \pm 0.75\end{array}$ & $22 \pm 6-27 \pm 7$ & $\begin{array}{l}120 \pm 58- \\
287 \pm 159\end{array}$ & & & $\begin{array}{c}1.93 \pm 0.56- \\
2.12 \pm 1.32\end{array}$ & & $\begin{array}{c}70 \pm 14-80 \pm \\
12\end{array}$ \\
\hline P. lividus ${ }^{6}$ & NW Mediterranean & Gonads & & $\begin{array}{c}0.88 \pm 0.34- \\
1.59 \pm 0.92\end{array}$ & $\begin{array}{l}2.68 \pm 0.94- \\
3.18 \pm 0.90\end{array}$ & $\begin{array}{c}35 \pm 17-101 \\
\pm 62\end{array}$ & & & $\begin{array}{l}1.38 \pm 0.70- \\
2.02 \pm 1.06\end{array}$ & & $\begin{array}{c}124 \pm 111- \\
161 \pm 192\end{array}$ \\
\hline P. lividus ${ }^{6}$ & NW Mediterranean & Body wall & & $\begin{array}{c}0.73 \pm 0.64- \\
0.89 \pm 0.77\end{array}$ & $\begin{array}{c}0.49 \pm 0.18- \\
0.65 \pm 0.28\end{array}$ & $\begin{array}{c}4.37 \pm 2.01- \\
13.7 \pm 8.7\end{array}$ & & & $\begin{array}{c}3.68 \pm 2.94- \\
5.39 \pm 3.50\end{array}$ & & $\begin{array}{c}3.84 \pm 0.78- \\
5.21 \pm 1.34\end{array}$ \\
\hline P. lividus $^{7}$ & NW Mediterranean & Digestive wall & & $\begin{array}{c}0.78 \pm 0.12- \\
1.74 \pm 1.54\end{array}$ & $\begin{array}{l}14.1 \pm 4.7- \\
31.1 \pm 7.3\end{array}$ & $\begin{aligned} 66 & \pm 7-320 \\
& \pm 166\end{aligned}$ & & & $\begin{array}{c}1.24 \pm 0.51- \\
4.90 \pm 0.72\end{array}$ & & $\begin{array}{c}54 \pm 10-88 \pm \\
16\end{array}$ \\
\hline P. lividus ${ }^{7}$ & NW Mediterranean & Gonads & & $\begin{array}{c}0.67 \pm 0.20- \\
2.16 \pm 1.13\end{array}$ & $\begin{array}{l}1.03 \pm 0.57- \\
3.83 \pm 0.59\end{array}$ & $\begin{array}{c}23 \pm 9-119 \\
\pm 66\end{array}$ & & & $\begin{array}{c}0.74 \pm 0.17- \\
3.02 \pm 1.31\end{array}$ & & $\begin{array}{l}53 \pm 51-383 \\
\pm 253\end{array}$ \\
\hline P. lividus $^{7}$ & NW Mediterranean & Body wall & & $\begin{array}{l}0.24 \pm 0.05- \\
2.05 \pm 0.15\end{array}$ & $\begin{array}{c}0.19 \pm 0.13- \\
0.86 \pm 0.12\end{array}$ & $\begin{array}{c}3.28 \pm 1.30- \\
17.9 \pm 14.3\end{array}$ & & & $\begin{array}{l}1.48 \pm 0.55- \\
7.76 \pm 0.83\end{array}$ & & $\begin{array}{c}3.08 \pm 0.85- \\
6.28 \pm 1.45\end{array}$ \\
\hline P. lividus & Balearic Islands & Full body tissues & $0.7-4.1$ & $0.4-3.2$ & $\begin{array}{l}1.6-7.5 \\
1\end{array}$ & & & $\begin{array}{l}0.8-2.7 \\
0.4\end{array}$ & $0.8-6.7$ & & $5.7-74.5$ \\
\hline P. lividus ${ }^{9}$ & Southern Adriatic Sea & Gonads & & & $5.19 \pm 2.68$ & $184 \pm 166$ & & & $0.86 \pm 0.67$ & & $\begin{array}{c}157.13 \pm \\
47.91\end{array}$ \\
\hline $\begin{array}{l}\text { Strongulocentrotus } \\
\text { intermedius and nudus }\end{array}$ & Amursky bay (Russia) & Gonads & & & 0,8 & 147 & & & & & 28,5 \\
\hline S. droebachiensis ${ }^{11}$ & Artic bay & Whole & $\begin{array}{c}3.5 \pm 0.6- \\
3.9 \pm 0.9\end{array}$ & & $\begin{array}{c}2.9 \pm 0.5- \\
3.2 \pm 0.5\end{array}$ & $\begin{array}{l}495 \pm 300- \\
1310 \pm 570\end{array}$ & & & & & $\begin{array}{c}34 \pm 5.8- \\
57 \pm 17 \\
\end{array}$ \\
\hline S. droebachiensis ${ }^{\text {hI }}$ & Artic bay & Gonads & $11 \pm 4.9$ & & $5.2 \pm 3.3$ & $217 \pm 58$ & & & & & $153 \pm 50$ \\
\hline Sphrerechinus granularis ${ }^{2}$ & Brest Bay & Gonads & 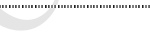 & & $3.7-5$ & $189-320$ & & & $0.79-1.14$ & & $476.4-706.3$ \\
\hline S. granularis & Brest Bay & Gut & & & $9.95-12.9$ & $4057-4601$ & & & $3.2-3.6$ & & $128.4-220.2$ \\
\hline 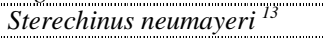 & King George Islands & Body wall & $0.04 \pm 0.01$ & $21.0 \pm 11$ & $7.0 \pm 4.0$ & $5400 \pm 3200$ & $100 \pm 50$ & $4.0 \pm 2.0$ & $10.0 \pm 6.0$ & $19 \pm 12$ & $260 \pm 60$ \\
\hline S. neumayeri ${ }^{13}$ & King George Islands & Digestive tract & $0.05 \pm 0.05$ & $23.0 \pm 12.0$ & $1.0 \pm 0.2$ & $300 \pm 100$ & $9 \pm 2$ & $2.0 \pm 1.0$ & $1.0 \pm 0.4$ & $9 \pm 1$ & $100 \pm 20$ \\
\hline S. neumayeri ${ }^{13}$ & Deception Island & Body wall & $1.0 \pm 1.0$ & $100 \pm 53$ & $0.2 \pm 0.1$ & $2400 \pm 1000$ & $100 \pm 30$ & $4.0 \pm 2.0$ & $13.0 \pm 5.0$ & $10 \pm 4$ & $620.0 \pm 136.0$ \\
\hline
\end{tabular}

${ }^{1}$ Flammang et al. $1997 ;{ }^{2}$ Buchanan et al. $1980 ;{ }^{3}$ Riley and Segar $1970 ;{ }^{4}$ Ablanedo et al. $1990 ;{ }^{5}$ Augier et al. $1989 ;{ }^{6}$ Warnau et al. $1995 ;{ }^{7}$ Warnau et al. $1998 ;{ }^{8}$ Deudero et al. $2007 ;{ }^{9} ;$ Storelli et al. 2001; ${ }^{10}$ Naidenko 1997; ${ }^{11}$ Bohn $1979 ;{ }^{12}$ Guillou et al. 2000; ${ }^{13}$ Deheyn et al. 2005; 
Table 5. Element concentrations (mean \pm S.D. or range; $\mu \mathrm{g} \mathrm{g}^{-1} \mathrm{dwt}$ ) in urchins from various geographical areas 
Figure 1

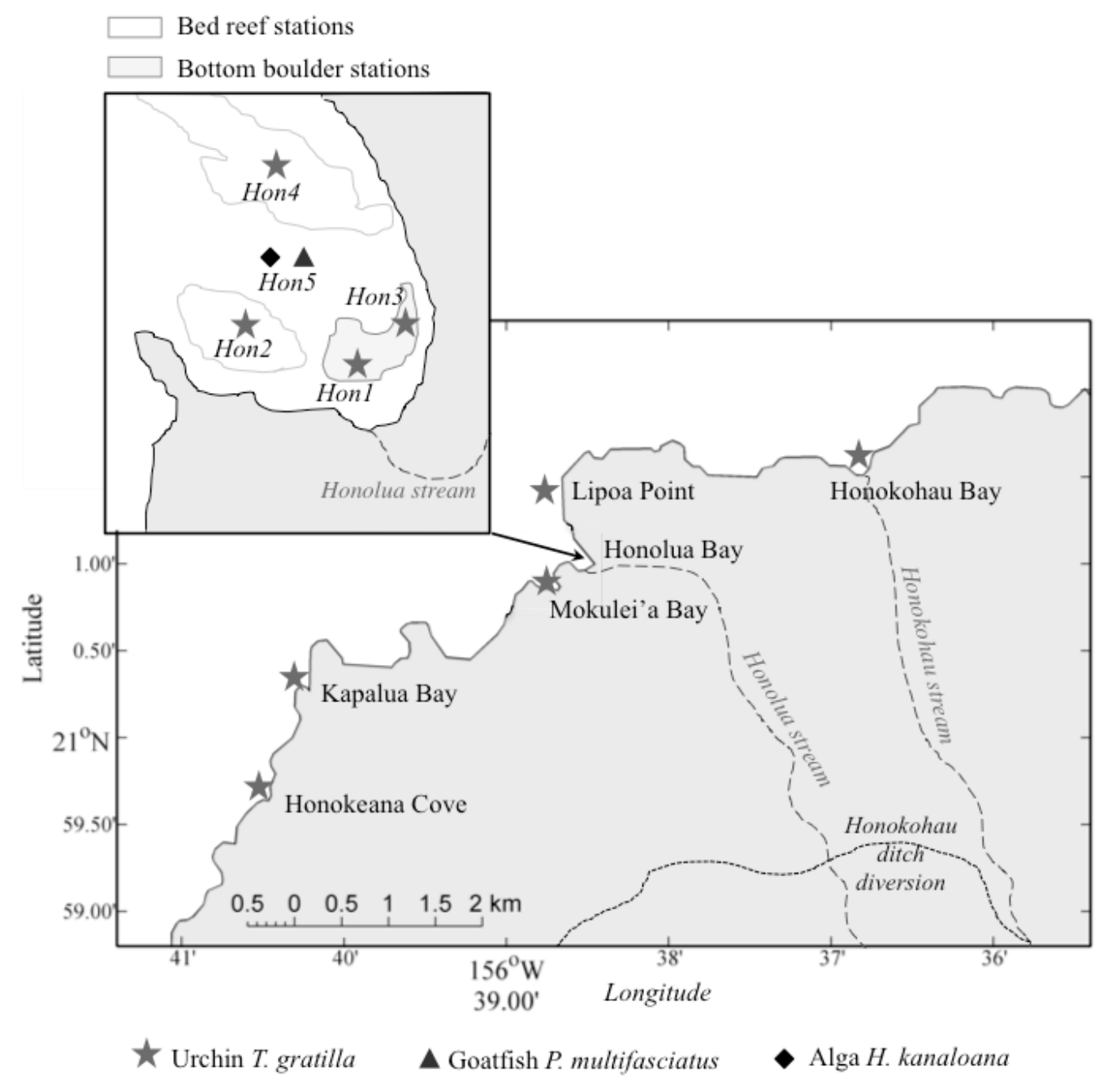

Geographical coordinates of the stations:

Hon $1\left(\mathrm{~N} 21^{\circ} 00.822\right.$, W $\left.156^{\circ} 38.332\right)$

Hon $3\left(\mathrm{~N} 21^{\circ} 00.844, \mathrm{~W} 156^{\circ} 38.277\right)$

Hon $2\left(\mathrm{~N} 21^{\circ} 00.835, \mathrm{~W} 156^{\circ} 38.405\right)$

Hon5 (N2 $\left.1^{\circ} 00.849, \mathrm{~W} 156^{\circ} 38.297\right)$

Hon4 (N2 $1^{\circ} 00.913$, W $\left.156^{\circ} 38.313\right)$

Kapalua Bay $\left(\mathrm{N} 21^{\circ} 00.046,156^{\circ} 40.057\right)$

Mokulei'a Bay $\left(\mathrm{N} 21^{\circ} 00.747\right.$, W156 38.517$)$

Lipoa Point (N2 $\left.1^{\circ} 01.046, \mathrm{~W} 156^{\circ} 38.419\right)$

Honokeana Cove $\left(\mathrm{N} 20^{\circ} 59.508\right.$, W156 $\left.{ }^{\circ} 40.124\right)$

Honokohau Bay $\left(\mathrm{N} 21^{\circ} 01.324, \mathrm{~W} 156^{\circ} 36.563\right)$ 


\section{Figure 2}

\section{A- Superficial sediments}

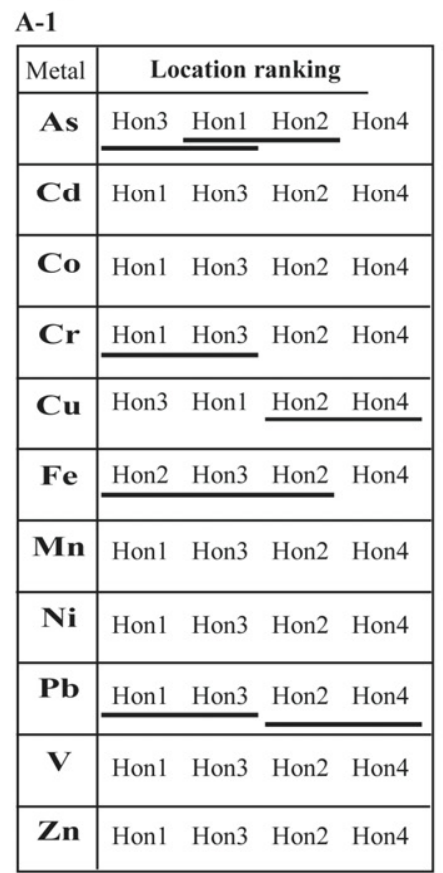

\begin{tabular}{|c|c|c|c|c|c|c|c|}
\hline \multirow{2}{*}{$\frac{\text { Metal }}{\text { As }}$} & \multicolumn{5}{|c|}{ Location ranking } & \multirow[b]{2}{*}{ LP } & \multirow[b]{2}{*}{ Hon4 } \\
\hline & $\mathrm{HB}$ & MB & Hon 1 & $\mathrm{~KB}$ & $\mathrm{HC}$ & & \\
\hline Cd & Hon 1 & $\mathrm{HB}$ & MB & $\mathrm{HC}$ & $\mathrm{KB}$ & LP & Hon4 \\
\hline Co & Hon1 & $\mathrm{HB}$ & MB & $\mathrm{HC}$ & $\mathrm{KB}$ & Hon4 & LP \\
\hline $\mathrm{Cr}$ & Hon1 & $\mathrm{HB}$ & MB & $\mathrm{HC}$ & $\mathrm{KB}$ & LP & Hon 4 \\
\hline $\mathbf{C u}$ & HB & Hon 1 & MB & $\mathrm{HC}$ & LP & $\mathrm{KB}$ & Hon4 \\
\hline $\mathbf{F e}$ & $\mathrm{HB}$ & Hon 1 & $\mathrm{MB}$ & $\mathrm{HC}$ & $\mathrm{KB}$ & LP & Hon4 \\
\hline Mn & Hon 1 & $\mathrm{HB}$ & MB & $\mathrm{HC}$ & $\mathrm{KB}$ & LP & Hon4 \\
\hline $\mathbf{N i}$ & Hon 1 & HB & MB & $\mathrm{HC}$ & $\mathrm{KB}$ & LP & Hon 4 \\
\hline $\mathbf{P b}$ & Hon1 & $\mathrm{HB}$ & MB & $\mathrm{HC}$ & $\mathrm{KB}$ & LP & Hon4 \\
\hline $\mathbf{V}$ & Hon1 & $\mathrm{HB}$ & MB & $\mathrm{KB}$ & $\mathrm{HC}$ & LP & Hon 4 \\
\hline $\mathbf{Z n}$ & Hon 1 & $\mathrm{HB}$ & MB & $\mathrm{HC}$ & KB & LP & Hon 4 \\
\hline
\end{tabular}

\section{B- Urchin T. gratilla}

B-1

\begin{tabular}{|c|c|c|c|c|c|}
\hline Metal & \multicolumn{5}{|c|}{ Location ranking } \\
\hline As & Hon1 & $\mathrm{KB}$ & Hon4 & LP & $\mathrm{HC}$ \\
\hline Cd & LP & $\mathrm{HC}$ & Hon 4 & Hon 1 & KB \\
\hline Co & Hon1 & Hon4 & LP & $\mathrm{HC}$ & $\mathrm{KB}$ \\
\hline $\mathrm{Cr}$ & Hon4 & Hon 1 & LP & KB & $\mathrm{HC}$ \\
\hline $\mathbf{C u}$ & Hon4 & Hon 1 & LP & $\mathrm{HC}$ & KB \\
\hline Fe & Honl & Hon4 & KB & LP & $\mathrm{HC}$ \\
\hline Mn & Hon1 & LP & $\mathrm{HC}$ & KB & Hon4 \\
\hline $\mathbf{N i}$ & Hon1 & Hon4 & LP & $\mathrm{KB}$ & $\mathrm{HC}$ \\
\hline $\mathbf{P b}$ & Hon4 & Hon1 & LP & $\mathrm{HC}$ & KB \\
\hline $\mathbf{V}$ & KB & Hon4 & Hon1 & LP & $\mathrm{HC}$ \\
\hline $\mathbf{Z n}$ & $\mathrm{KB}$ & Hon4 & Hon1 & LP & $\mathrm{HC}$ \\
\hline
\end{tabular}

B-2

\begin{tabular}{|c|c|c|c|}
\hline Metal & \multicolumn{3}{|c|}{ Compartment ranking } \\
\hline As & I & G & $\mathrm{C}$ \\
\hline Cd & I & G & $\mathrm{C}$ \\
\hline Co & I & G & $\mathrm{C}$ \\
\hline $\mathrm{Cr}$ & $\mathrm{C}$ & G & I \\
\hline $\mathbf{C u}$ & I & G & $\mathrm{C}$ \\
\hline $\mathbf{F e}$ & I & G & $\mathrm{C}$ \\
\hline Mn & I & G & $\mathrm{C}$ \\
\hline $\mathbf{N i}$ & I & G & $\mathrm{C}$ \\
\hline $\mathbf{P b}$ & $\mathrm{C}$ & I & G \\
\hline $\mathbf{V}$ & $\mathrm{C}$ & G & I \\
\hline $\mathbf{Z n}$ & I & G & C \\
\hline
\end{tabular}


Figure 3
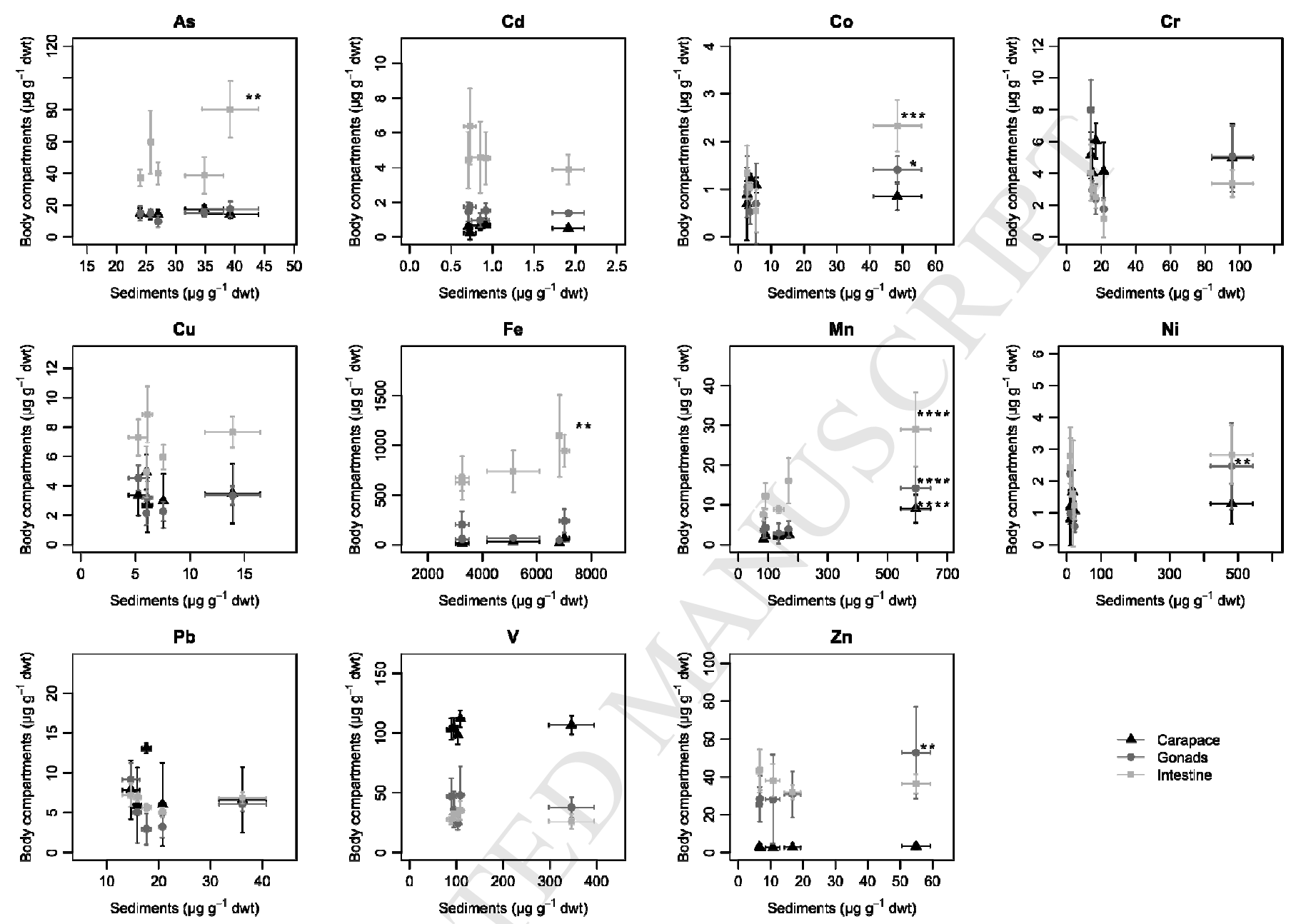

$\rightarrow$ Carapace

Intestine 
Figure 4

A) Coral cover composition

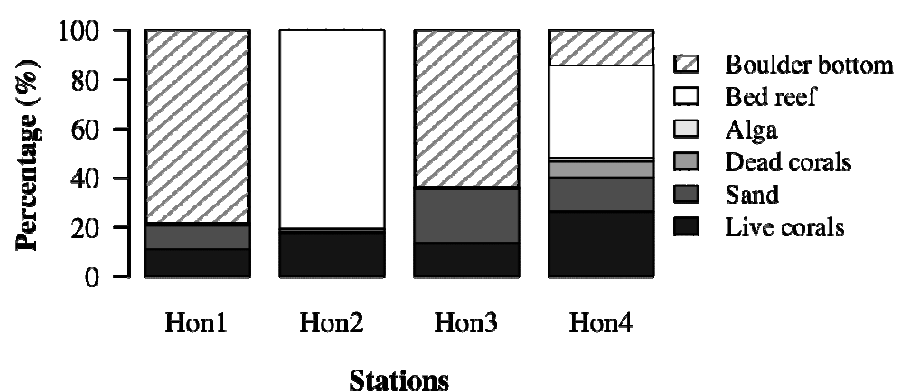

B) Coral species composition

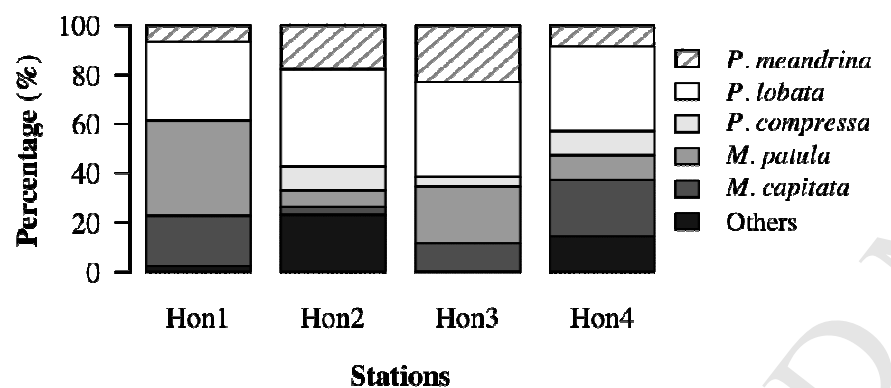

Stations
D) Diameter of the 5 most abundant coral species

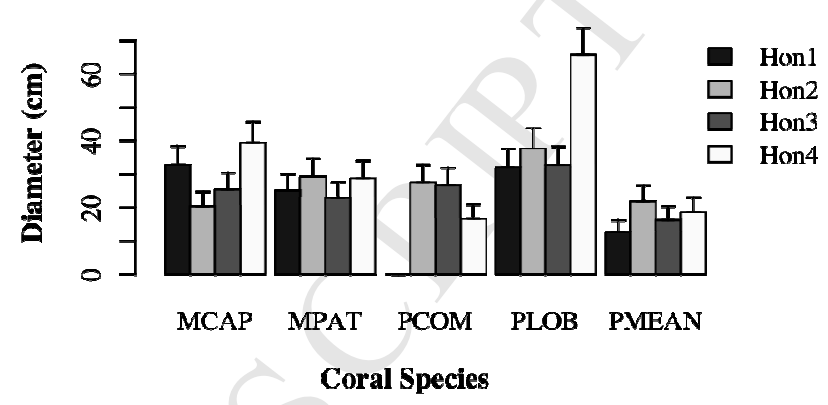

E) Mortality of the 5 most abundant coral species

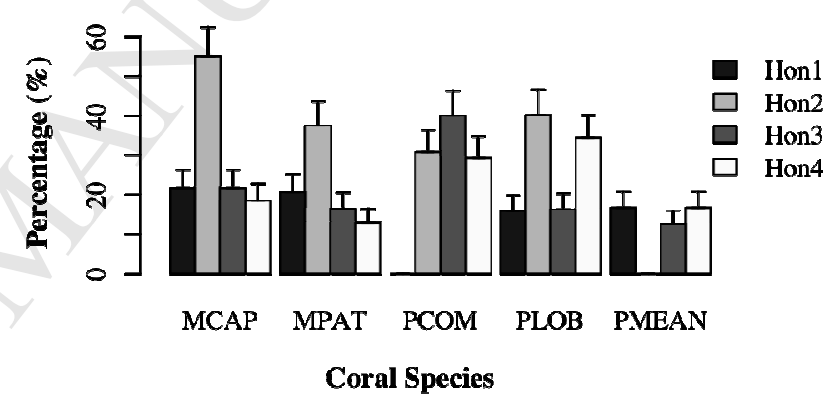

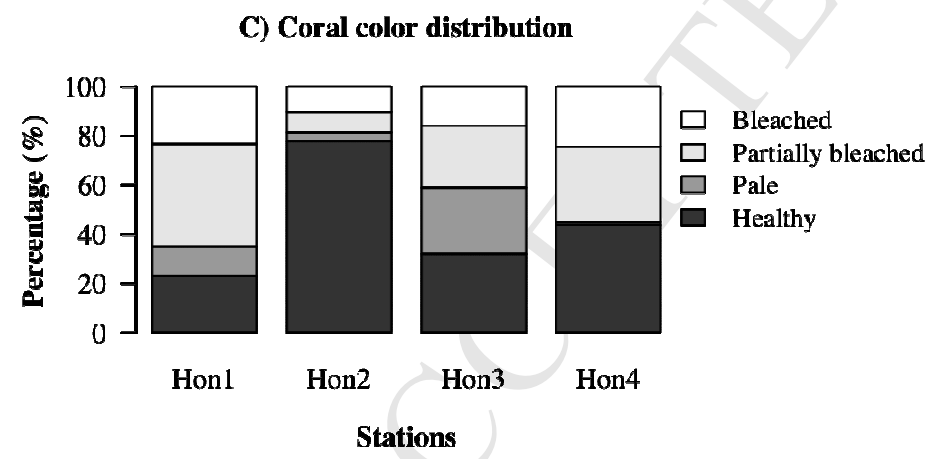


Figure 5

A- Cobalt

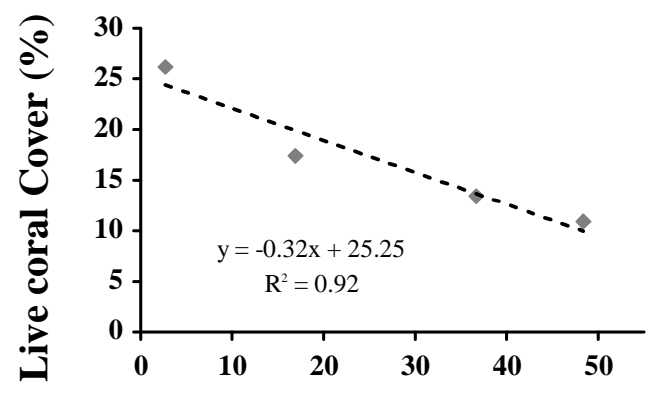

B- Vanadium

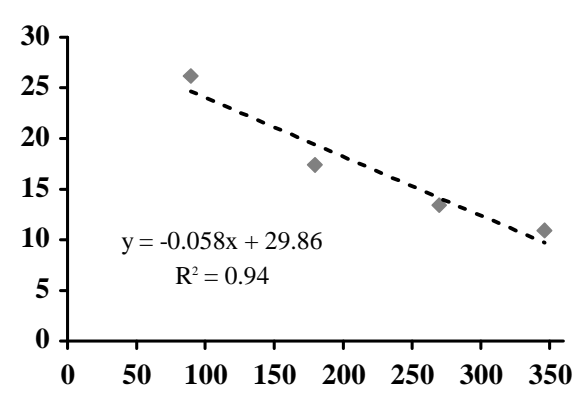

Element concentration $\left(\mu \mathrm{g} \mathrm{g}^{-1} \mathrm{dwt}\right)$ 
Figure 6

A) Turbidity

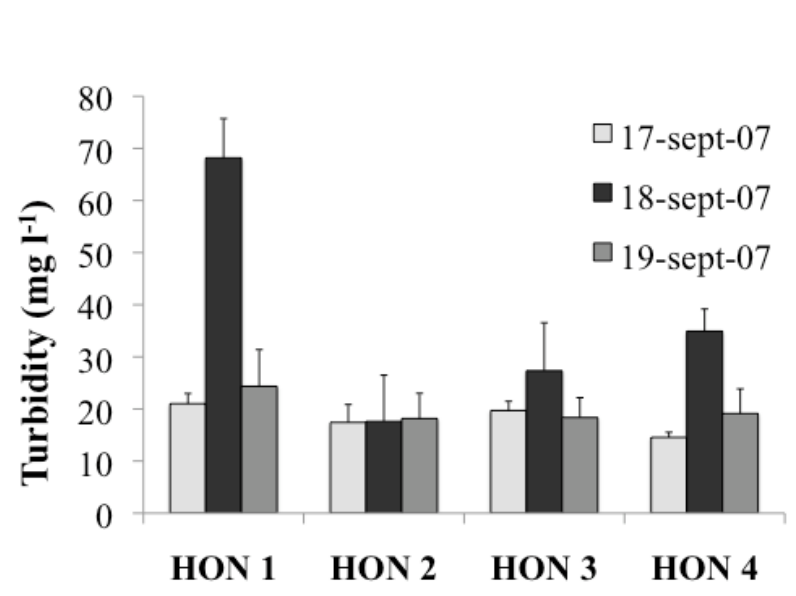

B) Temperature

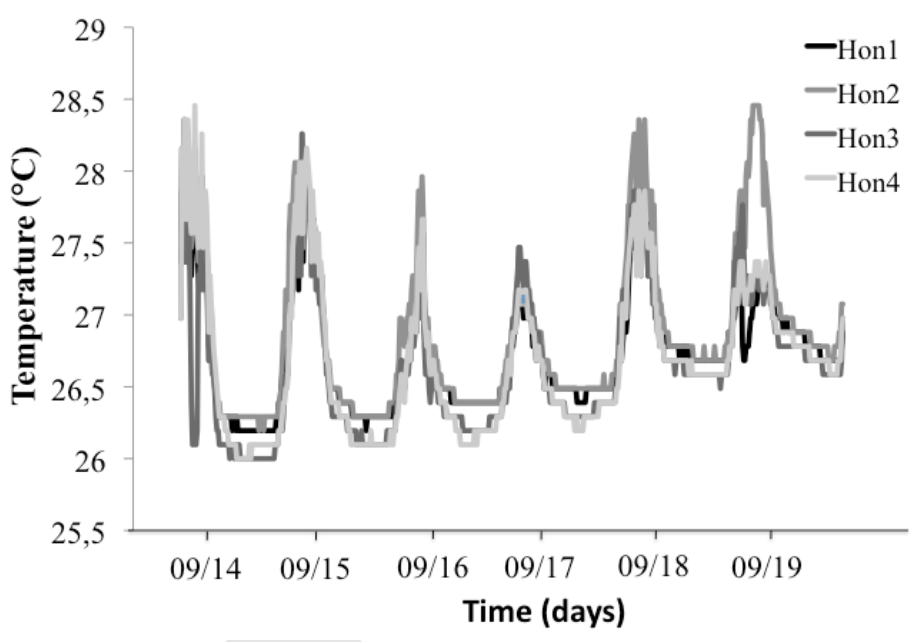

